\title{
Food defence systems as an answer to food terrorism
}

\author{
Karlo Jurica ${ }^{1}$, Josip Vrdoljak², and Irena Brčić Karačonji ${ }^{3}$ \\ ${ }^{1}$ Special Security Operations Directorate, Ministry of the Interior, Zagreb, Croatia \\ ${ }^{2}$ Pleter-usluge d.o.o., Zagreb, Croatia \\ ${ }^{3}$ Institute for Medical Research and Occupational Health, Zagreb, Croatia
}

[Received in October 2019; Similarity Check in October 2019; Accepted in November 2019]

Terrorist attacks on critical infrastructures can cause problems to a national stability and functioning. Food and water supply chains are some of the most important infrastructures, and it is the country's (government's) obligation to provide sufficient quantities of food and water to its population. Intentional food contamination can, among other motives, originate from an act of terrorism (with political or ideological motives) with the aim of causing fear (terror) among people. Food defence systems can help assess vulnerabilities, determine mitigation strategies for terrorist attack, estimate risks, and prevent a terrorist attack. Risk assessment and prevention also include control over the production and distribution of potential chemical, biological, radiological or nuclear (CBRN) agents or their related materials. When a terrorist attack occurs, rapid and organised response is essential in terms of determining the type of agent used, managing the diseased, ensuring the functioning of the food and water supply, and the recovery of the infrastructure system under attack. Food defence planning as part of a food counterterrorism strategy should include considerations regarding the global food market and the fact that ingredients are supplied from all over the world (vendor certificates). Preventing terrorist attacks on sources of food and water is a far better option than crisis management once an attack had already been committed, but governments should have a response to any scenario.

KEY WORDS: CBRN agent; critical infrastructure; intentional food contamination; risk assessment; system vulnerability

The $21^{\text {st }}$ century has brought new ways of warfare, as well as dangers to national stability. The stability of a country is closely related with the functioning and protection of its critical infrastructures. Instead of direct military conflict, attackers with ideological motives will often apply asymmetric war methods. The logical answer is action through homeland security and counter terrorist legislation.

Terrorism is unpredictable, which is exactly why it is necessary to consider potential targets of terrorist activity known as critical system points (such as the food or water supply chain). Intentional contamination of the food or water supply chain is called food terrorism (1). It is an act of deliberate contamination or a threat of intentional contamination of food for human consumption by chemical, biological, radiological or nuclear (CBRN) agents for the purpose of causing injury or death to the civilian population and/or disturbing the social, economic or political stability of a nation (2, 3). Agroterrorism (an aspect of food terrorism) is a malicious attempt by one or more persons to cause damage or destroy agriculture, the food industry or supply chains (4). Agroterrorism is considered to be a subset of food terrorism because the target is primary production (crops production and animal and fish farming)

Corresponding author: Karlo Jurica, $\mathrm{PhD}$, Special Security Operations Directorate, Ministry of the Interior, Ulica grada Vukovara 33, 10000 Zagreb, Croatia, E-mail: juricakarlo@gmail.com
(5) and it represents an asymmetric and non-traditional attack. CBRN agents for attacking agriculture, food, or water supply critical infrastructures pose a new challenge for police departments, security and intelligence agencies, as well as agencies dealing with food safety and public health.

If intentional contamination of food or water supply chain is not committed for ideological reasons but for other reasons, e.g. to destroy a competitor, it can be defined as food terror (the distinction from food terrorism is described later on). Each country must ensure the availability of sufficient quantities of food/water (food security) for the population as well as sufficient amounts of drinking water, especially in moments when a terrorist attack on the food/ water supply chain occurs. Negative impacts to political and social stability (risk of protest, rioting, conflicts, and democratic breakdown) could be caused by food insecurity (hunger as a result insufficiency of food and water) (6).

Weapons of mass destruction in countries that signed the Convention on the Prohibition of the Development, Production, Collection and Use of Chemical Weapons and on its Destruction (CWC) (7) and the Convention on the Prohibition of the Development, Production and Stockpiling of Bacteriological (Biological) and Toxin Weapons and on their Destruction (BTWC) (8) should not be present in any national laboratory legally unless for scientific or medical purposes, as the Conventions stipulate. Countries should be cautious in controlling national borders or shipments 
from countries that are not members of the Conventions. The government should have under control suspected terrorist groups and their activities in the region, or reach an agreement with countries in its vicinity on cooperation.

The scope of this review is to present an update of intentional food contaminations with known CBRN agents for the period 1998-2018, describe the characteristics of the used agents and food crime legislation, explain basic elements that have to be considered when protecting food, as well as propose responses to attacks at national level.

\section{LITERATURE SEARCH}

Our literature search relied on studies of intentional food contamination and risk assessment of food supply chain reported in articles covered by the PubMed database (1998-2019), international governmental organisations and databases, national guidelines, and news reports when original reports were unavailable. To filter them, we used combinations of the following key words: bioterrorism, intentional food contamination, homeland security, CBRN agents, food defence. Furthermore, we limited this review to data published in English and Croatian.

\section{LEGISLATIVE FRAMEWORK}

Food is defined as any substance or product, whether processed, partially processed or unprocessed, intended to be or reasonably expected to be ingested by humans. The term "food" includes drink, chewing gum and any substance, including water, intentionally incorporated into food during its manufacturing, preparation or treatment [Article 2, EUR-LEX 178/2002 (9)].

\section{Critical infrastructure legislation in various countries}

The European Union (EU) and its Member States have for some time now been trying to define which national critical infrastructures are of the highest significance and define a way of managing them, analyse risks, evaluate system vulnerabilities, and make a security plan for each critical infrastructure [EC Directive 2008/114/ EC (10)] The Republic of Croatia passed in 2013 the Critical Infrastructures Act (11) and in 2017 released a draft of the Act on Homeland Security (12).

In 1989, the United Kingdom (UK) passed the Security Service Act defining the protection of national security, in particular against threats of espionage, terrorism or sabotage, from the activities of a foreign force, which could jeopardize parliamentary democracy (13), in 2000 the Terrorism Act (14), which provided the definition of terrorism, while the Anti-Terrorism, Crime and Security Act 2001 (15), adopted on November 19, 2001, allows the UK Government the right to fight terrorism, control immigration, freeze terrorists' property, monitor and control weapons of mass destruction, increase safety related to toxins, pathogenic organisms, nuclear industry, and increase the authority of the police.

The Centre for the Protection of National Infrastructure (CPNI), founded in 2007 in the UK (16), defined 13 critical infrastructures important for national security, including chemicals, food, water, health, and transport. The National Infrastructure Security Coordination Centre (NISCC) and the National Security Advice Centre (NSAC) were also established (17). In 2014, the British Standard Institution defined malicious activities targeting the food and food supply chain in the Food and Drink Protection Guide. These categories are: economically motivated adulteration, malicious intentional food contamination, extortion, espionage, food counterfeiting, and cyber-crime (16).

The Homeland Security Act from 2002, also called the Critical Infrastructure Information Act, recognized the food sector as one of the 17 critical infrastructures in the US (18). The US government identified the food and agriculture sector as a critical infrastructure, as the destruction or disabling of this sector would have a negative impact on citizen safety, national economic security, and national health (19).

In 2002, the US issued the Public Health Security and Bioterrorism Preparedness and Response Act (20), in which they developed national preparedness and responses to a terrorist act that would endanger food/water. This law also includes improvements in public health, to centers for disease control and prevention (CDCPs), or national emergency health system. It has been developed as a countermeasure and response to bioterrorist attacks. This includes additional control of hazardous biological agents and toxins (Department of Health and Human Services, Department of Agriculture) and protection of food from counterfeiting and adulteration as well as defence of food supply/drug supply chain, controls and inspection of food facilities in the US, and food import facilities. In order to prepare the US public health system and primary healthcare providers to address various biological agents, the CDCP classified biological agents into three categories with regard to the level of risk they pose to national security: category A (high priority agents: Bacillus anthracis, Clostridium botulinum toxin, Yersinia pestis, Variola major, Francisella tularensis, filoviruses, and arenaviruses) includes organisms that are easily transmitted to the general population, have high mortality rates and significant impact on public health, might cause public panic and social disruption, and require special action for public health preparedness; category B (second highest priority agents: Brucella species, epsilon toxin of Clostridium perfringens, Salmonella species, Escherichia coli O157:H7, Shigella, Burkholderia mallei, Burkholderia pseudomallei, Chlamydia psittaci, Coxiella burnetii, ricin toxin from Ricinus communis, Staphylococcal enterotoxin B, Rickettsia prowazekii, alphaviruses, Vibrio cholerae, and Cryptosporidium parvum) includes those that are moderately easy to disseminate, result in moderate 
morbidity rates and low mortality rates, and require specific enhancements of CDC's diagnostic capacity and enhanced disease surveillance; and category $\mathrm{C}$ (third highest priority agents: Nipah virus and hantavirus) includes emerging pathogens that could be engineered for mass dissemination in the future because of availability, ease of production and dissemination, and potential for high morbidity and mortality rates and major health impacts (21).

The Food Safety Modernization Act (FSMA) (22) passed in 2010 gives the US Food and Drug Administration (FDA) the power to create new standards and rules to prevent foodborne/waterborne diseases. The reasoning behind this decision was to keep track of the modernization and complexity of the food supply system, changes in the nature of the food industry, higher quantity of food present on the market, as well as new dangers in food that had not been known until then.

\section{Food crime legislation}

There are no specific laws or regulations for food crimes in the US, but there is a general criminal law that could be applied (23).

According to US criminal law (24), terrorism is defined in $\$ 2332$ as a violent act dangerous to human life and it is a violation of the criminal law of the US or any of its states and it would be a criminal violation if committed within the jurisdiction of US. $\S 2332$ also describes the use of weapons for mass destruction against US as a serious offense inside and outside the country (Chapter 113B). The same law prohibits biological (Chapter 10) and chemical (Chapter 11B) weapons. Destruction of national defence materials, premises, or utilities including livestock, water, food, food stuff suitable for the use by the US or an associated nation is defined as sabotage (Chapter 105, $\S 2151)$.

The European Union does not have a single criminal law to describe food crimes or any kind of crime at all, but the Member States have their own criminal laws (23).

In the Republic of Croatia, the Criminal Code (25) defines some terms that could be applied in practice. A criminal act involving an attack on a critical infrastructure (food/water) can be caused by the production or marketing of products harmful to human health (Article 188) by an unconscious inspection of meat for human consumption (Article 189), or by endangering people's lives and property with generally dangerous actions or instruments (Article 215), by an act of terrorism (Article 97), or destruction or damage to public devices (Article 216). The criminal code describes what constitutes criminal responsibility, an act that can be committed by an individual or a group who intentionally performs that act, and who was aware or should have been aware that he or she was committing a criminal offense (Article 23). Criminal offenses can be committed by acting or failing to act (Article 20). According to the Criminal Code of the Republic of Croatia, even an attempt to commit a criminal offense is punishable (Article $34)$.

\section{Food terror and food terrorism - differences}

Terrorism by Croatian criminal law is defined as: "Whoever, with the aim of seriously intimidating the population, or forcing a State, or an international organization to act or not to act, or seriously violate or destroy the fundamental constitutional, political, economic or social structures of the State or an international organization, commits one of the acts (endanger the lives of people, the destruction of state infrastructure, public facilities, property, produce, possess or use the weapons, explosives, nuclear, biological or chemical weapons or research those weapons, releasing hazardous substances, causing fire, floods or explosions that endanger peoples life, obstruct the water supply, electricity or basic natural resources, possesses or uses radioactive substances, uses a radioactive material or uses instrument releasing the radioactivity or damages a nuclear facility), which could seriously damage the state, committed an act of terrorism" (25) (Figure 1).

Food terrorism examples have rarely been described in the literature and they are usually unconfirmed (26-28), such as Salmonella in ridden eggs scheduled for sale on the Israeli market (machine for counterfeiting the egg stamps was discovered) which resulted in one possible death (26, 27 ); Ebola virus injected by armed men in water pumps and wells in Liberia which resulted in 16 possible deaths (29); bleach added to food (Taliban terrorist claimed to kill five people in a NATO base in Afghanistan) (28).

Food terror is a broader concept than food (agro) terrorism, because it describes a criminal act involving the food/water supply chain as an act of deliberate contamination of food/water for human consumption by a certain agent (biological, chemical, physical, radiological), but the motive is quite different than classical food terrorism, which encompasses ideological motives for causing the injury or death of a civilian population or the disturbance of social, economic or political stability. Food terror is an act motivated by revenge, or to frighten someone, to destroy competitor food manufacturers, to sabotage food products but not an entire country, or due to the mental instability of the perpetrator (Figure 1). An example are needles in strawberries placed by the individual for revenge, as was the case recently in Australia (30); ethylene glycol spiked in baby food in supermarkets in Germany in order to extort money (31); mixing pesticide into sweets sold in a shop in Pakistan after an argument (32); rat poison injected into tea drinking products in four supermarkets by a man 'angry with the world' (28); one of the largest intentional mass poisonings in the United States was caused by drinking coffee spiked with arsenic by the church parishioner who admitted the crime in a suicide note saying that he just wanted to give people a stomach ache (33); the death of 


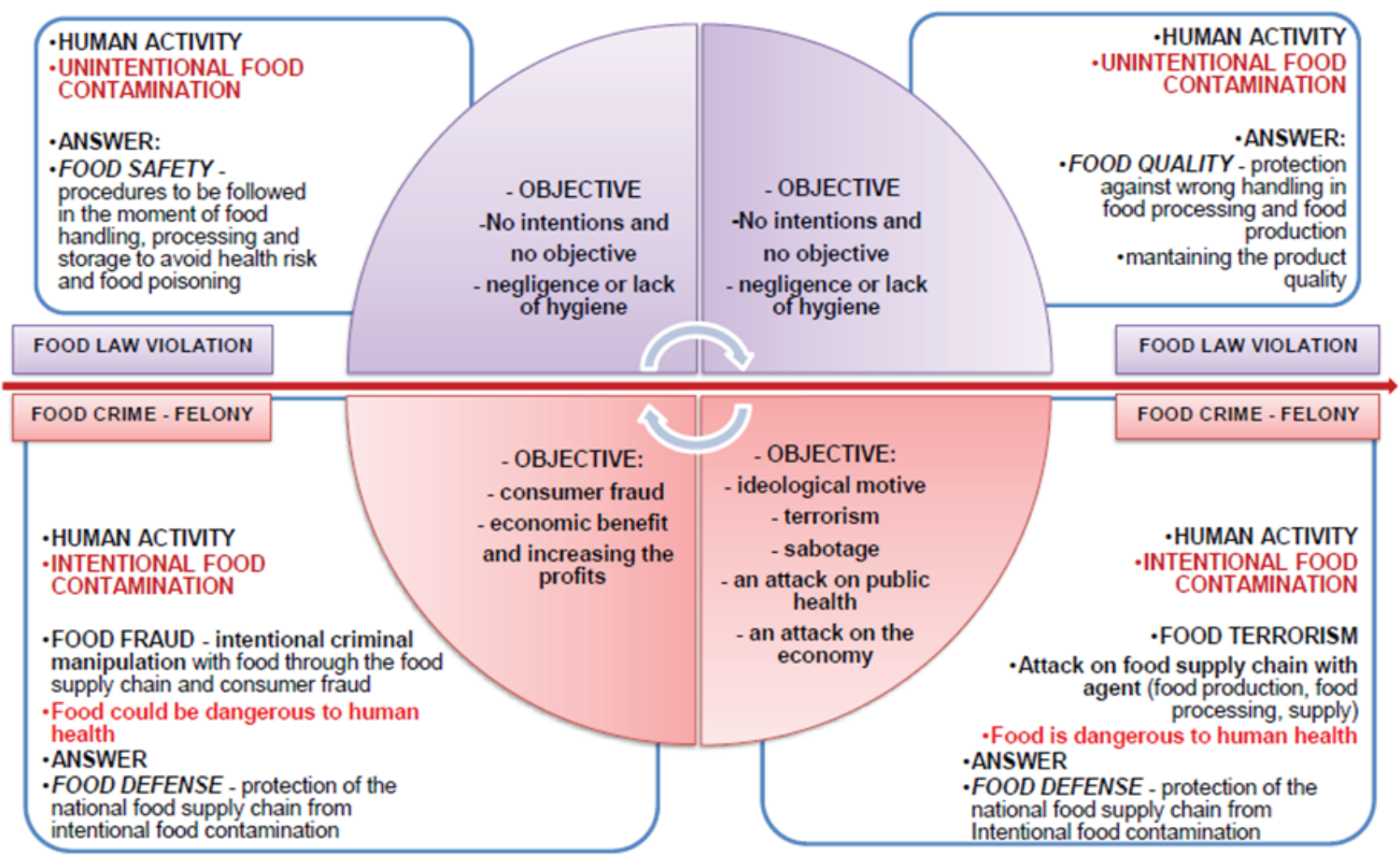

Figure 1 Food law violation and Food crime (71), adjusted

ex-KGB agent Litvinenko after ingesting radioactive polonium-210 in his tea (27); Shigella dysenteriae type 2 (in 1996) found in pastries left in the lunchroom by a laboratory technician who had access to the Shigella cultures in the St. Paul Medical Center hospital in Dallas that resulted in 13 employees falling ill (26).

For law enforcement, the main key is to qualify the act that happened according to the criminal law and homeland security directives as well as codes describing terrorism. The police could, after the evaluation of the criminal act, set up a model for how to behave with a perpetrator or offender. All food crimes have the common denominator of an intentional act but with different motives for food fraud (fraudulent activity with economical gain) and for food crime (ideological motive, terrorism, attack on the state's economy, sabotage, or food terror) (Figure 1).

\section{FOOD DEFENCE SYSTEMS IN THE FOOD SUPPLY CHAIN}

The FDA published Food Safety Guidelines for food manufacturers, food processors and food carriers, food importers, food stores, hospitality and catering facilities, dairy industry and processors and carriers in the cosmetic industry (34).
Food Safety and Inspection Service at the United States Department of Agriculture (USDA FSIS) FOOD defence guidelines and tools

The Food Safety and Inspection Service (FSIS) in the US provided food protection guidelines for all food manufacturers, importers, carriers and distributors. These documents are designed to help the food industry develop their own strategies of preventing deliberate food contamination. These tools include: Food Protection Guide for Slaughterhouses and Processing Plants (35), Food Defence Guides for Warehouses and Distribution Centres (36), Food Defence Guidelines for the Transportation and Distribution of Meat, Poultry, and Processed Egg Products (37), Food Defence Guide to Freshwater Fish (38), Food Protection Guide for the Transportation of Agricultural Products and Foodstuffs (39), and Food Protection Guide for Disposing of Deliberately Contaminated Food and Decontamination of Production Facility (40).

The food supply chain is considered to be global, because the raw material or food ingredients could come from any corner of Earth (41) (Figure 2).

The final food product is compiled from many ingredients and raw materials purchased on the global food market (Figure 2) and they could already be contaminated during any phase of food production, food processing, food transportation, food storage, food sale or food preparation in household or public restaurants (food supply chain) (Figure 3). To trust the supplier of the food ingredients or raw material, one has to implement the food defence systems into the production process within the quality management systems that comprise food defence systems 
in their norms [FSCC 22000 (42), BRC Food Standard 8 (43), PAS 96 (44), IFS Food Version 6.1 (45), SQF Quality Code (35)]. All suppliers should possess food defence certificates for their food. Others in the food supply chain (food industry, transportation, retail) should implement food defence procedures and politics in their facilities as a guarantee for secure and safe products regarding intentional contamination.

\section{INTENTIONAL FOOD CONTAMINATION}

Intentional food contamination can cause the spread of fear to the public and have serious consequences for public health or a national economy. The public can lose confidence in food safety or a government's efficiency. The likelihood of a successful attack largely depends on the accessibility to the target and the availability of the contaminating agent.

Methods of intentional food contamination could be (46):

1. External attack: raw materials used in food production can be contaminated at the point where they are grown, transported or processed. Raw food is more likely available than finished food products. Contaminated raw material enters the production and processing facility through normal distribution routes.

2. Forceful entrance to a food production and processing facility: a person who intends to contaminate food enters forcefully into the food production facility. Food suspected to be contaminated may be removed (whole LOTs) if another activity related to a forceful entry has been excluded such as vandalism or theft.

3. Secret entry to a food processing facility: entering a food process facility secretly, fraudulently or as part of a visiting group (e.g. drive-through students or system consultants) to gain access to food at some stage of production.

4. Inside collaborator: an attacker who has committed intentional food contamination in the production facility has taken advantage of legitimate access to food that an employee has in the food production facility.

\section{CBRN (chemical, biological, radiological or nuclear) agents}

Many potential CBRN agents can be found in surrounding food chains (primary production, food processing, food distribution, food preparation). Some are pesticides, fertilizers, additives, preservatives and household chemicals which could be improperly used or misused. Table 1 shows the main potential biological and chemical agents that can be used to intentionally contaminate food and water.

A biological agent can be any organism or toxin produced by a living organism capable of causing disease in humans, plants and animals (47). The desirable characteristics of biological agents are stability in extreme circumstances like food processing, heating or UV light, exponential multiplication in short time, and pathogenicity. Considerable technical knowledge and financial background are needed for such an attack.

A toxic chemical agent is any chemical that can cause death, temporary inability or permanent damage to humans and animals, regardless of where the chemical agent is produced, with its chemical action on the biological system (organism) (7). If the chemical agent is colourless, odourless or the same colour as the food, the vulnerability of the food supply chain step will be higher (48).

System vulnerability is more sensitive to chemical agents and toxins than to biological agents. The main reason is that during the food manufacturing process, several microbiological controls are performed, whereas there is much less control for chemical contaminants (48). Also, food processing which implies heat treatment or other kinds of sterilisation (ultraviolet light) remove most of the biological treats. One exception is anthrax that is rather persistent in spore form, regardless of processing (5).

Radiological agents are radioactive elements that may appear in the form of a liquid or solid and should be taken
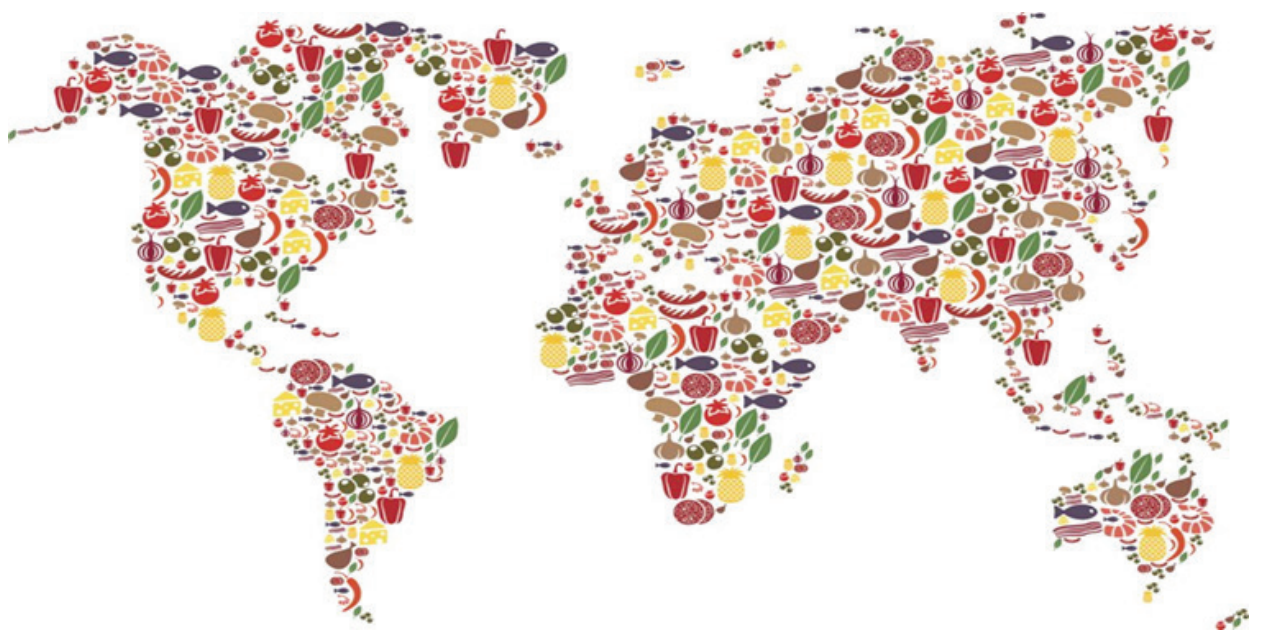

Figure 2 World Food Program USA by Karl Deily (41) 
Table 1 The main potential biological and chemical agents that can be used to intentionally contaminate food and water $(48,68-70)$

\begin{tabular}{|c|c|c|c|}
\hline $\begin{array}{l}\text { Microorganism / } \\
\text { Biological agent }\end{array}$ & Disease & Toxicity & Symptoms of poisoning \\
\hline Bacillus anthracis & Anthrax & ID: $8,000-50,000$ spores & $\begin{array}{l}\text { Abdominal pain, fever, vomiting, } \\
\text { bloody diarrhoea, and shock }\end{array}$ \\
\hline Bacillus cereus & $\begin{array}{l}\text { 1. Diarrheal type of } \\
\text { illness } \\
\text { 2. Vomiting (emetic) } \\
\text { type of illness }\end{array}$ & ID: $10^{5}-10^{8}$ organisms & $\begin{array}{l}\text { 1. Watery diarrhoea, abdominal } \\
\text { cramps, and pain } \\
\text { 2. Nausea and vomiting }\end{array}$ \\
\hline Brucella sp. & Brucellosis & ID: $10-100$ organisms & $\begin{array}{l}\text { Fever, sweating, malaise, aches, and } \\
\text { pains }\end{array}$ \\
\hline Burkholderia mallei & Glanders & ID: unknown & $\begin{array}{l}\text { Inflammation of mucus membranes } \\
\text { of the nose, cough, chest pain, fever, } \\
\text { rigors }\end{array}$ \\
\hline $\begin{array}{l}\text { Burkholderia } \\
\text { pseudomallei }\end{array}$ & Melioidosis & ID: unknown & $\begin{array}{l}\text { Acute septicaemic condition with } \\
\text { diarrhoea }\end{array}$ \\
\hline Clostridium perfringens & & $\begin{array}{l}\text { Several million } C . \\
\text { perfringens per gram of } \\
\text { food }\end{array}$ & $\begin{array}{l}\text { Abdominal pain, diarrhoea, and } \\
\text { possibly nausea }\end{array}$ \\
\hline Campylobacter sp. & Enterocolitis & ID: $<500$ organisms & Invasive diarrhoea \\
\hline Coxiella burnetii & Q fever & ID: 10 spores & $\begin{array}{l}\text { Mild symptoms (chills, headaches, } \\
\text { fever, chest pains, perspiration, loss } \\
\text { of appetite) }\end{array}$ \\
\hline Escherichia coli & Enterocolitis & ID: $10^{6}-10^{8}$ organisms & $\begin{array}{l}\text { Gastrointestinal (diarrhoea, } \\
\text { vomiting) dehydration; }\end{array}$ \\
\hline $\begin{array}{l}\text { Escherichia coli } \\
\mathrm{O} 157: \mathrm{H} 7\end{array}$ & Enterocolitis & ID $<10$ organisms & Acute bloody diarrhoea \\
\hline Francisella tularensis & Tularemia & ID: $10^{8}$ organisms & Influenza-like symptoms \\
\hline Listeria monocytogenes & Listeriosis & ID: $10^{7}-10^{9} \mathrm{CFU}$ & $\begin{array}{l}\text { Fever, muscle aches, nausea, } \\
\text { diarrhoea, headache, stiff neck, } \\
\text { confusion, loss of balance, } \\
\text { convulsions }\end{array}$ \\
\hline Salmonella sp. & Salmonellosis & ID: $10^{4}-10^{5}$ organisms & Vomiting and diarrhoea \\
\hline Shygella dysenteriae & Shigellosis & ID: $10-100$ organisms & $\begin{array}{l}\text { Diarrhoea, abdominal pain, and } \\
\text { bloody stools }\end{array}$ \\
\hline Staphylococus aureus & Enterocolitis & ID: $10^{5}-10^{8} \mathrm{CFU}$ & $\begin{array}{l}\text { Nausea, vomiting, and abdominal } \\
\text { cramping }\end{array}$ \\
\hline Vibrio cholerae & Cholera & ID: 1,000 organisms & $\begin{array}{l}\text { Profuse watery diarrhoea, rapid } \\
\text { dehydration, and a state of collapse }\end{array}$ \\
\hline $\begin{array}{l}\text { A and B } \\
\text { Coxsackieviruses }\end{array}$ & Bornholm disease & ID: $<3 \times 10^{3}$ organisms & $\begin{array}{l}\text { Fever, headache, and severe pain in } \\
\text { the lower chest }\end{array}$ \\
\hline Adenoviruses & Enteritis & ID: $5-10^{4}$ organisms & $\begin{array}{l}\text { Diarrhoea, vomiting, headache, } \\
\text { fever, and stomach cramps }\end{array}$ \\
\hline Hepatitis A virus & Hepatitis & ID: $2-10^{4}$ organisms & $\begin{array}{l}\text { Fever, loss of appetite, diarrhoea, } \\
\text { nausea, abdominal discomfort, dark- } \\
\text { coloured urine and jaundice }\end{array}$ \\
\hline Rotavirus & Gastroenteritis & ID: $<100$ virus particles & $\begin{array}{l}\text { Vomiting, abdominal distress, } \\
\text { diarrhoea, and dehydration. }\end{array}$ \\
\hline Toxin & Origin & Toxicity* & Symptoms of poisoning \\
\hline Abrin & $\begin{array}{l}\text { Seeds of Abrus } \\
\text { precatorius (jequirity } \\
\text { bean) }\end{array}$ & $\begin{array}{l}\text { LD: } 0.1-1 \mu \mathrm{g} / \mathrm{kg} \\
\text { (no antidote) }\end{array}$ & $\begin{array}{l}\text { Gastrointestinal haemorrhage } \\
\text { (bloody diarrhoea) with organ } \\
\text { necrosis; death can occur in } 36-72 \mathrm{~h}\end{array}$ \\
\hline Aflatoxins & $\begin{array}{l}\text { Aspergillus flavus } \\
\text { (mould) }\end{array}$ & $\begin{array}{l}\text { Fatal at high levels within a } \\
\text { short period (no antidote) } \\
\quad \mathrm{LD}_{50}\left(\mathrm{~B}_{1}\right): 1 \mathrm{mg} / \mathrm{kg}\end{array}$ & $\begin{array}{l}\text { Jaundice, rapidly developing } \\
\text { ascites (abdominal fluid), and portal } \\
\text { hypertension }\end{array}$ \\
\hline
\end{tabular}




\begin{tabular}{|c|c|c|c|}
\hline Alpha amanitin & $\begin{array}{l}\text { Amanita phalloides } \\
\text { (death cap mushroom) }\end{array}$ & $\mathrm{LD}_{50}: 0.1 \mathrm{mg} / \mathrm{kg}$ & Liver and kidney failure \\
\hline Alpha-toxin & Clostridium perfringens & $\begin{array}{c}\mathrm{LD}_{50}: 3 \mu \mathrm{g} / \mathrm{kg} \text { (mouse, } \\
\text { intravenous) (no antidote) }\end{array}$ & $\begin{array}{l}\text { Necrotic enteritis, delirium, and } \\
\text { coma }\end{array}$ \\
\hline Anatoxin A & Anabaena flos-aquae & 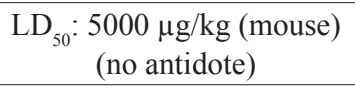 & $\begin{array}{l}\text { Loss of coordination, paralysis, and } \\
\text { respiratory arrest }\end{array}$ \\
\hline Botulinum toxin & Clostridium botulinum & $\mathrm{LD}_{50}$ (oral): $1 \mu \mathrm{g}$ & $\begin{array}{l}\text { Progressive paralysis from head to } \\
\text { toe }\end{array}$ \\
\hline Ciguatoxin, maitotoxin & $\begin{array}{l}\text { Gamberdiscus toxicus } \\
\text { (dinoflagellate) }\end{array}$ & $\begin{array}{l}\text { Ciguatoxin }\left(\mathrm{LD}_{50}\right): 0.25 \mu \mathrm{g} / \\
\mathrm{kg} \text { (mouse, intravenous) } \\
\text { Maitotoxin }\left(\mathrm{LD}_{50}\right): \\
0.13 \mathrm{ug} / \mathrm{kg} \text { (mouse, } \\
\text { intraperitoneal) }\end{array}$ & $\begin{array}{l}\text { Nausea, abdominal pain, vomiting, } \\
\text { diarrhoea, reversal of hot and cold } \\
\text { sensation, muscle and joint ache }\end{array}$ \\
\hline $\begin{array}{l}\text { Diacetoxyscirpenol } \\
\text { (DAS) }\end{array}$ & $\begin{array}{l}\text { Mycotoxin from } \\
\text { Fusarium sp. }\end{array}$ & $\begin{array}{l}\mathrm{LD}_{50}: 2-16 \mathrm{mg} / \mathrm{kg} \\
\text { (rodents) }\end{array}$ & $\begin{array}{l}\text { Vomiting, inflammation, } \\
\text { haemorrhages, diarrhoea }\end{array}$ \\
\hline Diphtheria toxin & $\begin{array}{l}\text { Corynebacterium } \\
\text { diphtheriae }\end{array}$ & $\begin{array}{l}\mathrm{LD}_{50}: 100 \mathrm{ng} / \mathrm{kg} \\
\text { (intramuscular) }\end{array}$ & $\begin{array}{l}\text { Myocarditis, neuritis, kidney } \\
\text { function impairment }\end{array}$ \\
\hline $\begin{array}{l}\text { Escherichia coli } \\
\text { enterotoxins }\end{array}$ & $\begin{array}{l}\text { Enterotoxigenic } \\
\text { Escherichia coli }\end{array}$ & $\begin{array}{c}\text { ID: } 10^{8}-10^{10} \text { organisms } \\
\text { of Enterotoxigenic } \\
\text { Escherichia coli }\end{array}$ & Severe diarrhoea \\
\hline Microcystin & $\begin{array}{l}\text { Cyanobacteria } \\
\text { Microcystis spp. }\end{array}$ & ID: $1-10 \mathrm{mg}$ & Fever, convulsions, and headache \\
\hline Nicotine & $\begin{array}{l}\text { Nicotiana tabacum } \\
\text { (tobacco plant) }\end{array}$ & LD: $60 \mathrm{mg}$ & $\begin{array}{l}\text { Excess oral secretions and } \\
\text { sweating, vomiting, diarrhoea, } \\
\text { abdominal cramping, confusion, and } \\
\text { convulsions }\end{array}$ \\
\hline Palytoxin & Palythoa corals & $\begin{array}{l}\text { LD: } 600 \mu \mathrm{g} / \mathrm{kg} \text { (mouse) } \\
\text { (no antidote) }\end{array}$ & $\begin{array}{l}\text { chest pains, breathing difficulties, } \\
\text { tachycardia, unstable blood pressure }\end{array}$ \\
\hline Ricin & $\begin{array}{l}\text { Beans of castor plant } \\
\text { Ricinus communis }\end{array}$ & $\begin{array}{l}\mathrm{LD}_{50}: 1 \mathrm{mg} / \mathrm{kg} \text { (no } \\
\quad \text { antidote) }\end{array}$ & $\begin{array}{l}\text { Gastrointestinal haemorrhage } \\
\text { (bloody diarrhoea) with organ } \\
\text { necrosis; death can occur in } 36-72 \mathrm{~h} \\
\text { (no antidote) similar to abrin }\end{array}$ \\
\hline Saxitoxin & $\begin{array}{l}\text { Marine dinoflagellate } \\
\text { Protogonyaulax sp. }\end{array}$ & $\begin{array}{l}\text { LD: } 0.3-1.0 \mathrm{mg} \\
\text { (no antidote) }\end{array}$ & $\begin{array}{l}\text { Abdominal distress, diarrhoea, } \\
\text { nausea, vomiting, vertigo, headache, } \\
\text { rapid pulse, and numbness of } \\
\text { the tongue and gums, leading to } \\
\text { paralysis }\end{array}$ \\
\hline Shiga toxin & $\begin{array}{l}\text { Shigella dysenteriae } \\
\text { and enterohemorrhagic } \\
\text { Escherichia coli }\end{array}$ & $\begin{aligned} \mathrm{LD}_{50}: & 2 \mathrm{ng} / \mathrm{kg} \text { (mouse, } \\
& \text { parenteral) }\end{aligned}$ & $\begin{array}{l}\text { Abdominal pain, watery diarrhoea, } \\
\text { haemorrhagic colitis }\end{array}$ \\
\hline $\begin{array}{l}\text { Staphylococcal } \\
\text { enterotoxin B }\end{array}$ & Staphylococcus aureus & $\begin{array}{l}\text { ID: } 20-25 \mu \mathrm{g} \text { (no } \\
\text { antidote) }\end{array}$ & $\begin{array}{l}\text { Severe gastrointestinal pain, } \\
\text { projectile vomiting, and diarrhoea }\end{array}$ \\
\hline $\mathrm{T}-2$ toxin & $\begin{array}{l}\text { Mycotoxin from } \\
\text { Fusarium and some } \\
\text { other genera of fungi }\end{array}$ & $\mathrm{LD}_{50}: 1.6 \mathrm{mg} / \mathrm{kg}$ & $\begin{array}{l}\text { Light headache, nausea, vomiting, } \\
\text { and diarrhoea }\end{array}$ \\
\hline Tetrodotoxin & Pufferfish $(f u g u)$ & LD: 1-2 mg (no antidote) & $\begin{array}{l}\text { Numbness of the lips, tongue, and } \\
\text { fingers, anxiety, nausea, vomiting, } \\
\text { and other symptoms, progressing } \\
\text { with time to paralysis. Death, usually } \\
\text { within } 6 \mathrm{hr} \text {, is due to respiratory } \\
\text { failure. }\end{array}$ \\
\hline
\end{tabular}




\begin{tabular}{|c|c|c|c|}
\hline Chemical agent & Class & Toxicity* & Symptoms of poisoning \\
\hline Arsenic & Metalloid & LD: $70-180 \mathrm{mg}$ & $\begin{array}{l}\text { Vomiting, diarrhoea, dehydration, } \\
\text { multisystem organ failure }\end{array}$ \\
\hline Barium & Metal & $\mathrm{LD}_{50}: 132 \mathrm{mg} / \mathrm{kg}$ (rat) & $\begin{array}{l}\text { Vomiting, abdominal pain, and } \\
\text { watery diarrhoea, hypokalaemia, } \\
\text { paralysis }\end{array}$ \\
\hline Chromium VI & Metal & LD: $4.1 \mathrm{mg} / \mathrm{kg}$ & $\begin{array}{l}\text { Irritation, ulceration and non- } \\
\text { neoplastic lesions of the stomach and } \\
\text { small intestine }\end{array}$ \\
\hline Cyanide & $\begin{array}{l}\text { Salts (sodium or } \\
\text { potassium) }\end{array}$ & LD: $1.52 \mathrm{mg} / \mathrm{kg}$ & $\begin{array}{l}\text { Headache, nausea/vomiting, } \\
\text { cardiovascular collapse }\end{array}$ \\
\hline Digoxin & Cardiac glycoside & LD: $10 \mathrm{mg}$ & $\begin{array}{l}\text { Nausea, vomiting, hyperkalaemia, } \\
\text { and dysrhythmias }\end{array}$ \\
\hline Dioxin & Industrial by-product & $\mathrm{LD}_{50}: 22 \mu \mathrm{g} / \mathrm{kg}$ (rat) & Chloracne \\
\hline Ethylene glycol & Antifreeze agent & LD: $1,400-1,600 \mathrm{mg} / \mathrm{kg}$ & $\begin{array}{l}\text { Vomiting, metabolic acidosis, renal } \\
\text { failure }\end{array}$ \\
\hline Fentanyl & Opioid & LD: $2 \mathrm{mg}$ & $\begin{array}{l}\text { Lethargy or coma, decreased } \\
\text { respiratory rate, miosis, bradypnea, } \\
\text { and possibly apnea }\end{array}$ \\
\hline Lewisite & Chemical warfare agent & LD: $50 \mathrm{mg} / \mathrm{kg}$ (rat) & $\begin{array}{l}\text { burn of mouth and throat, severe } \\
\text { stomach pain, nausea, vomiting, and } \\
\text { bloody stools }\end{array}$ \\
\hline $\begin{array}{l}\text { LSD (lysergic acid } \\
\text { diethylamide) }\end{array}$ & Hallucinogen & ED: $50 \mu \mathrm{g}$ & $\begin{array}{l}\text { Sweating, rapid heartbeat, tremor, } \\
\text { blurred vision, distorted sense of } \\
\text { time, visual hallucinations. }\end{array}$ \\
\hline Mercury (Inorganic) & Salt (mercuric chloride) & LD: $10-42 \mathrm{mg} \mathrm{Hg} / \mathrm{kg}$ & $\begin{array}{l}\text { Cardiovascular collapse, acute renal } \\
\text { failure, and severe gastrointestinal } \\
\text { damage }\end{array}$ \\
\hline Paraquat & Herbicide & LD: $35 \mathrm{mg} / \mathrm{kg}$ & $\begin{array}{l}\text { Pain in the mouth and throat, nausea, } \\
\text { vomiting, abdominal pain, diarrhoea, } \\
\text { heart, liver, and kidney failure }\end{array}$ \\
\hline Polonium-210 & Radioactive element & LD: $50 \mathrm{ng}$ & $\begin{array}{l}\text { Severe diarrhoea, vomiting, and hair } \\
\text { loss }\end{array}$ \\
\hline $\begin{array}{l}\text { Sodium } \\
\text { monofluoroacetate } \\
(\text { Compound 1080) }\end{array}$ & Pesticide & $\mathrm{LD}_{50}: 2-5 \mathrm{mg} / \mathrm{kg}$ & $\begin{array}{l}\text { Metabolic acidosis, hypotension, } \\
\text { dysrhythmias, seizures, coma, and } \\
\text { respiratory depression }\end{array}$ \\
\hline Strychnine & Rodenticide & LD: $30-120 \mathrm{mg}$ & $\begin{array}{l}\text { Muscle spasms and cramps, stiffness } \\
\text { and tightness, agitation, heightened } \\
\text { awareness and responsiveness, and } \\
\text { respiratory failure }\end{array}$ \\
\hline Sulphur mustard & Chemical warfare agent & LD: $0.7 \mathrm{mg} / \mathrm{kg}$ & $\begin{array}{l}\text { Abdominal pain, diarrhoea, fever, } \\
\text { nausea, and vomiting }\end{array}$ \\
\hline Superwarfarin & Rodenticide & LD: $15 \mathrm{mg}$ & $\begin{array}{l}\text { Gingival bleeding, petechial } \\
\text { haemorrhages, and intracranial } \\
\text { haemorrhages }\end{array}$ \\
\hline Tetramine & Rodenticide & LD: $7-10 \mathrm{mg}$ & Seizure and coma \\
\hline White phosphorus & Rodenticide & $\begin{array}{l}\text { TD: } 15 \mathrm{mg} \\
\text { LD: } 50 \mathrm{mg}\end{array}$ & $\begin{array}{l}\text { Severe vomiting, diarrhoea, garlic- } \\
\text { like odour, dysrhythmias, coma, and } \\
\text { hypotension }\end{array}$ \\
\hline Thallium & Rodenticide & LD: $54-110 \mathrm{mg} / \mathrm{kg}$ & $\begin{array}{l}\text { Abdominal pain, painful ascending } \\
\text { neuropathy, seizures, and hair loss }\end{array}$ \\
\hline
\end{tabular}

*Route of exposure: oral, otherwise stated. Note: lethal doses were expressed as stated in the cited literature. Whenever a dose is expressed in $\mathrm{mg}, \mu \mathrm{g}$, or $\mathrm{ng}$, this refers to an adult person of $70 \mathrm{~kg}$ in weight. $\mathrm{LD}$ - lethal dose; $\mathrm{LD}_{50}$ - lethal dose for $50 \%$ of test sample; ID - infectious dose; TD - toxic dose; ED - effective dose 
into account for the possibility of causing acute and chronic health effects. They could be of natural origin or industrial by-products and include any radiological substance (5).

Nuclear agents are a subgroup of radiological agents and are not of natural origin and should be processed for use as a threat in intentional food contamination. Attacks with radionuclear agents are very uncommon due to the hard accessibility of raw materials (5).

The US Department of Homeland Security (DHS) monitors biological and chemical agents that could be used by terrorists, and these substances are difficult to obtain in large quantities.

The expected consequences and effects of CBRN contaminations in the food chain include health casualties, economic losses, social and political disruption.

\section{CRITICAL POINTS FOR AGENT ENTRANCE INTO THE FOOD/WATER SUPPLY CHAIN}

The magnitude of a food chain CBRN attack depends on the type and quantity of the CBRN agent used, its point of entry, human resistance to an agent and possibility of applying a proper medical treatment as well as the speed of discovery by national or local authorities.

Dangerous biological agents are deadly or very infectious, resistant to environmental factors, not easily destroyed, have a low infectious dose, transmitted by air, water and food, transmitted from man to man, cheap and easily produced (49).

It is very hard to make a distinction between terrorism and criminal activity because the nature of these agents is such that whatever the underlying motivation behind their use, biological, chemical and radiological agents have the potential to do significant harm, or create an atmosphere of fear and panic.

When predicting possible consequences and effects, one should be aware of the different factors resulting from diverse methods to produce, process, transport, store, and prepare food, as well as cultural and geographical differences. Thus, actual risks have to be assessed on a case-by-case basis.

\section{Food production - crops and animal farming}

Cases involving intentional contamination at this point of the food supply chain could cause economic losses due to the deaths of numerous animals or the destructions of crops, but they would probably not result in any human fatalities due to the tests implemented before they can be sold on the market (27). Apart from direct losses of animals and crops which would have evident changes or symptoms in their organic systems visible to monitoring systems, there are also indirect losses due to compensation or protective trade embargos (50).
Food primary production includes plant production, animal farming and open raw water areas to be used for potable water production. This stage of the food chain is the most unprotected and vulnerable point of the food supply chain.

Attacks with CBRN agents in the plant production phase would probably be discovered fast because of noticeable changes in the affected plants (morphological changes, plant decay etc.). Therefore, incidents involving the intentional contamination of crops that ended up in the food supply chain are extremely rare. Only one incident was recorded in 2006 in Australia when a water tank used by a crop duster was contaminated with glyphosate, which caused visible changes in the crops. Despite noticeable changes, laboratory tests showed that the contamination level was not high enough to preclude one farm out of the three affected to place their crops on the market and later issue a recall. The incident resulted in a loss of one million Australian dollars (27). Crops can also be attacked, apart from chemicals, with crop diseases and crop-eating organisms that can cause large-scale damage (5). Because of the fast wide spreading of biological agents on large cultivated areas, crop diseases represent potential hazards for plants (Figure 3). Nowadays, food production facilities have better control through quality management and national monitoring systems so any change in the plant organism caused by an agent should be noticed and would probably result only in economic damage (5).

A deliberate attack with CBRN agents on livestock in farming should also be discovered quickly because of visible changes in animal organisms. One such incident was the poisoning of the water supply to a farm in Alabama (USA) with cyanide in 1970 that resulted in the death of 30 cattle (27). Veterinary legislation suggests that a national body has jurisdiction over animal health protection and their welfare with constant surveillance (Ministry for Agriculture - Veterinary Department). So animal farming facilities if they are legal should have a permanent veterinary inspection. Definition of healthy and safe livestock as food for human consumption suggests that ill or dead livestock is forbidden for human consumption [EUR-LEX, 852/2004 (51)]. Veterinary inspectors and veterinarians have an obligation to report if animals have infectious diseases and/ or major illnesses during farming (52). Livestock can be contaminated with biological agents either directly (e.g. by injecting different viruses) or indirectly by contamination of food ingested by animals (e.g. anthrax-infected food) (5). The most probable contamination of livestock (that could go into the food chain contaminated in the phase of farming) is with antibiotics and mycotoxins. A hazard for food supply system could occur if a competent authority does not obey legal procedures of feeding or applying antibiotics. 


\section{Food processing}

Food processing includes milling, smoking, baking, air-drying, freeze-drying, blanching, jellying, freezing, fermentation, preserving in salt, sugar, alcohol or olive oil, pickling, and canning. All of the ingredients entering the food processing phase must have clear traceability (certificate standards) during admission (53).

Processing will probably decrease the toxicity of the agent although an increase of toxicity cannot be excluded. If food processing facilities have food defence systems implemented (entrance control of visitors, couriers, external associates, part-time employees; security alarms and cameras; product not directly accessible during processing, etc.) the main problem for intentional food contamination could be an insider threat. This threat could be partially resolved by security checks of employees or by controlling critical points in each subunit of a food processing facility. Also, quality control procedures should be capable of detecting the contaminating agent (Figure 3).

Food processing companies, during the combining of ingredients into the final product, should have a certificate for each ingredient that guarantees the ingredients are CBRN agent-free. Quality management systems regarding ingredients and final food products that offer solutions are FSSC 22000 (42), IFS ver.6 (45), BRC (43), recognised by GFSI (Global Food Safety Initiative) (54). Ensuring the safety of the final food products is imperative for all serious food-processing companies to prevent potentially unwanted global consequences (Figure 2).

\section{Food transportation}

Transportation is a phase in which food is transported from one place to another satisfying all food safety standards (traceability, temperature regime), practically from the food production phase as the initial one (farming, crop production, ingredients), food processing as the second and the distribution of final product to retailers as the third phase (Figure 3) (27). Contamination with CBRN agents is possible in all points of transportation. Control over transport firms, vehicles and their employees, with delivery announcement in advance (name of the employee, registration mark for the vehicle), or lock up the transportation storage part, and unlocking registration should offer more confidence in the safety of the product or ingredient. All products should have their original packaging without damage or misleading labels.

Contamination in the transportation phase is more likely to occur if food is in liquid form rather than solid condition, packed in plastic rather than glass or exposed to air (such as bakery products), transported with simple or refrigerated trucks rather than in sealed liquid trucks (54).

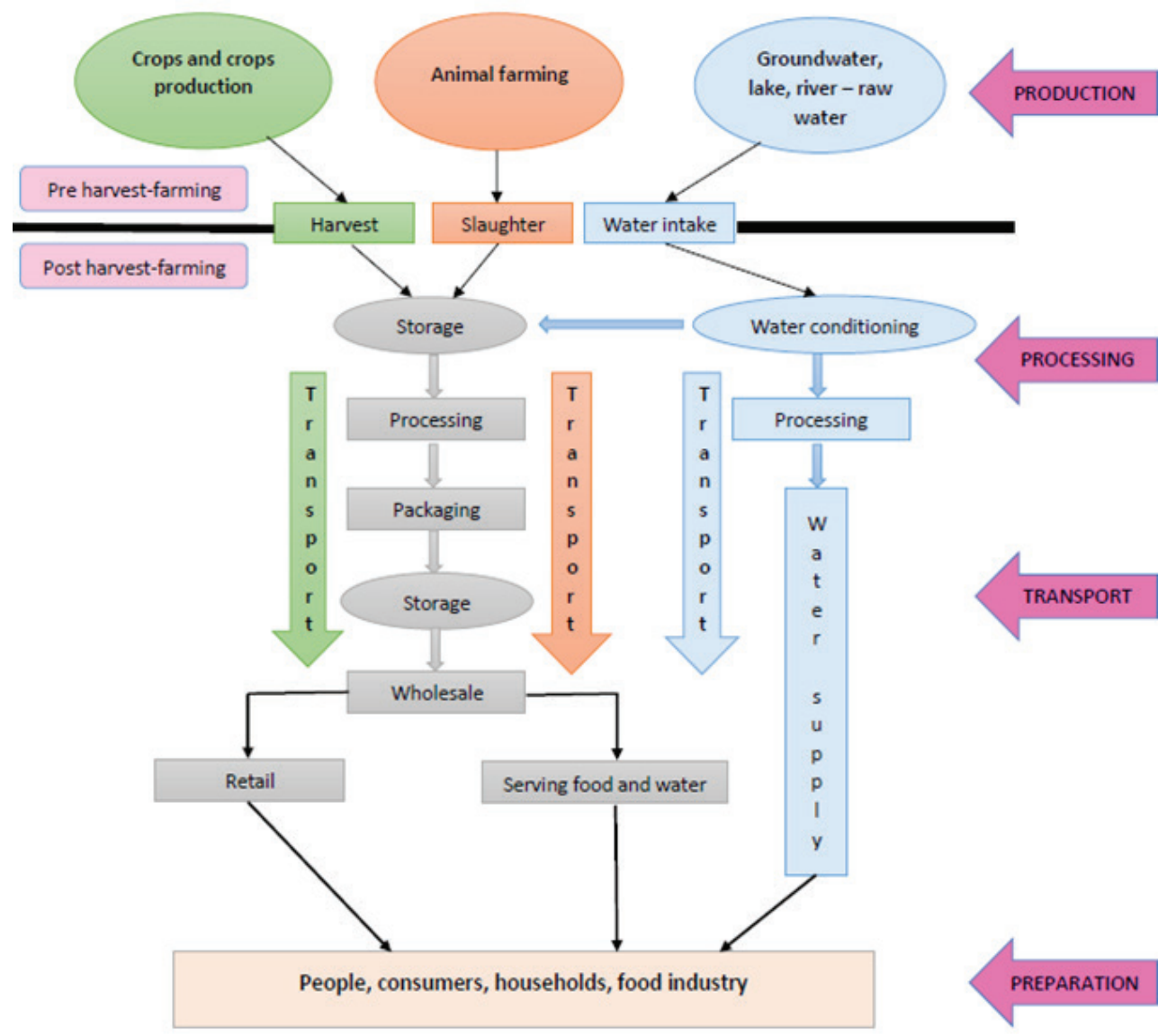

Figure 3 Food Defence Incidents 1950-2008 (27), adjusted 


\section{Food storage}

For the warehouse phase, vulnerability depends on the same factors as in the manufacturing and transportation phases: policies regarding visitors and employees, security measures, type of packaging as well as type of warehouses: non-refrigerated warehouses are more vulnerable to attacks (Figure 3)

\section{Food preparation}

Intentional food contamination occurs most frequently in the food preparation phase (before consumption) because of the vulnerability due to increased accessibility of unpacked raw food. In this phase, it is possible to cause intentional and accidental food contamination. Incidents at this phase have involved the heaviest casualties reported (27).

Contamination and poisonings of food with CBRNagents in this phase of the food chain is the least frequent food terroristic activity (but present nonetheless!), because it seems to be more personal and not directed at a larger population (no ideological or political motive). It is more of a food terror activity (criminal) with the motive to bring harm to someone because of personal feelings or to destroy the competition through sabotage.

The addition of a CBRN agent into prepared food is completely under the control of the perpetrator. Due to the lack of further food processing in this phase, it is very likely that CBRN agents will retain their toxic potential, but there is no further distribution through the food chain system resulting in harm only to specific individuals (less than five or no casualties) (27). According to Dalziel (27), almost $98 \%$ cases of intentional contamination of the food supply chain occur at the consumer's home or workplace and the most common agents used are household, agricultural, or industrial chemicals.

Human poisonings and poisoning attempts with known agents are presented in Table 2. Among the chemical agents used in food attacks, rat poison (anticoagulant) is the most frequently used, followed by cyanide-based products, pesticides, insecticides, arsenic, anti-freeze fluid and ricin.

\section{The water supply chain}

The water supply system has three important requirements (sufficient amount of water, sufficiently high flow rates and pressure in the system, and needs to be safe to consumers) that maintain the specific functions of the water supply system. In the US, the water supply system has been deemed as incapable of being fully protected (lifting more fences, prevention of access, more locks, more security cameras, and more security guards) especially at the first point of the water supply system (large quantities of water - agent dilution). The elimination of biological pathogens from water for human consumption is carried out by ordinary water processing such as chlorination, ozonisation, ultraviolet radiation, ordinary filtration, which is the first line of defence (55). The spore form of anthrax (agent Bacillus anthracis) is probably of the greatest concern due to its persistency (5). Chemical agents have been used in water supply poisoning in a number of attacks and associated deaths or illnesses (28). Compared to food attacks, water attacks are much more likely to be linked to political motives and much less likely to be successful because of the large quantity of agent required (due to the dilution effect) and less specific planning.

Water processing facilities (vulnerable point) should be more strongly controlled by physical control, video surveillance, and entrance as well as access control. Control of water during distribution through pipelines could be adequate at the levels of water flow and pressure control as well as control of measuring points or possible open parts of the system.

\section{HOW TO PROTECT THE FOOD/WATER SUPPLY CHAIN?}

The National Agricultural and Food Defence Strategy at state level must be carried out in cooperation with the Ministry of Health and the Ministry of Agriculture as well as in coordination with Homeland Security. The strategy must include an implementation plan that will be used by responsible persons from the ministries, and be revised every four years by the heads of Homeland Security, Ministry of Health and the Ministry of Agriculture (56).

In order to protect food in a particular vital state system of food/water production or in any part of the supply chain, it is necessary to perform risk assessment following a certain order.

First, the vulnerabilities of a system/supply chain (Vulnerability Assessment of Critical Control Points, VACCP) should be assessed, mitigation strategies should be adopted, and then the action plan should be designed as part of the mitigation strategy. When considering the type of threat, one needs to assess system vulnerabilities and potential threats or type of agents (Threat Assessment Critical Control Point, TACCP) that could harm the production/supply chain of food/water. Then the Food Defence Plan for production system/supply chain (Figure 4) needs to be implemented (57).

\section{VULNERABILITY ASSESSMENT OF CRITICAL CONTROL POINTS IN THE FOOD/WATER SUPPLY CHAIN (VACCP)}

Vulnerability is a weakness in system design that can be used to deliberately contaminate food or the ease by which a contaminant can be introduced in sufficient quantities to achieve the purpose of the attacker after he or she gains access to a critical point of the food supply system. Identifying and defining weak points in the food/water 


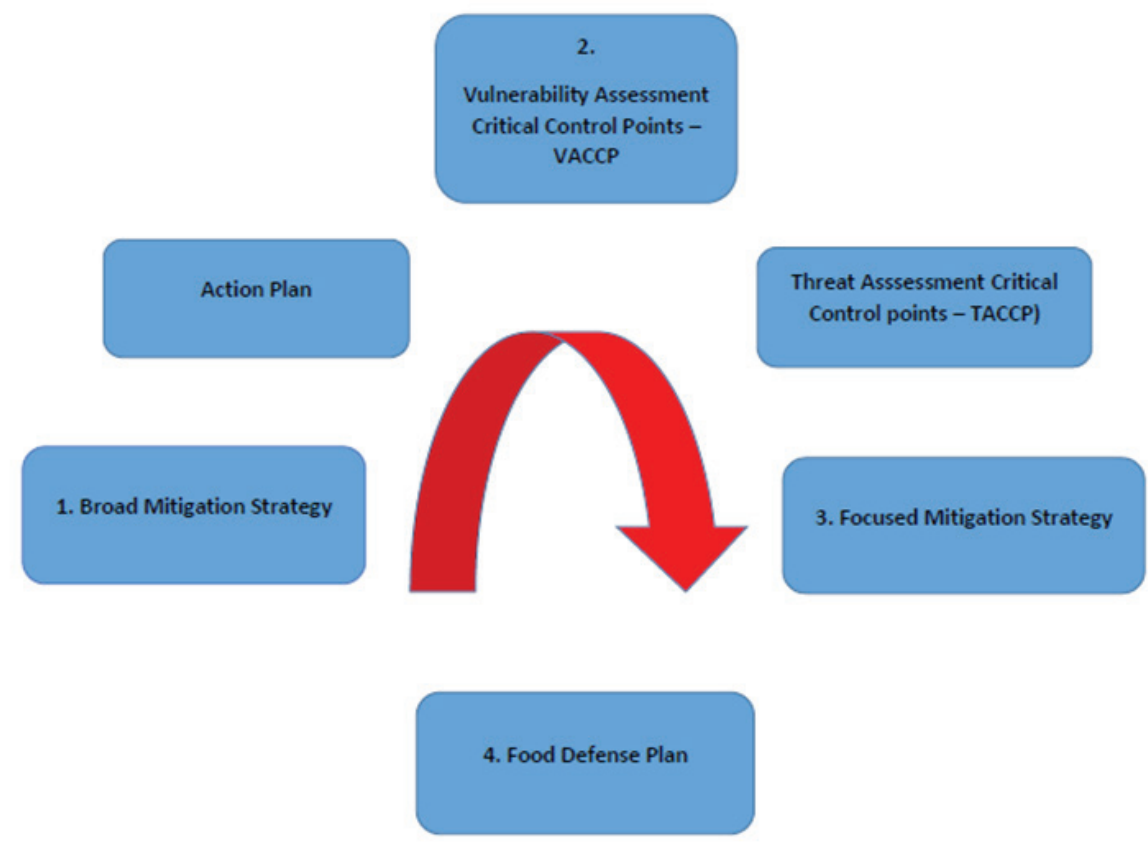

Figure 4 Food defence planning (57), adjusted

supply system in terms of potential deliberate food contamination that could harm the economy and public health is crucial when assessing the risk(s) and vulnerability of the system (58).

Since 2005, FDA has been using the CARVER+ Shock program to evaluate the vulnerability of the food supply chain system (58). Parameters are set up, then experts gather, food chain specificities are determined, points are assigned [conditions associated with lower attractiveness or vulnerability are assigned lower values (1 or 2), whereas conditions associated with the higher attractiveness of the target or higher vulnerability are assigned higher values (9 or 10)], and estimations are ultimately obtained. CARVER is an acronym for Criticality, Accessibility, Recuperability, Vulnerability, Effect, and Recognizability.

Criticality: the food product can be more critical if the introduction of an agent at this point had a significant health or economic impact on the state.

Accessibility: the food product is more available to an attacker when he or she can easily obtain a product to conduct the attack, contaminate the food product, and remain undiscovered. Accessibility implies the susceptibility of a target to a threat agent and is the measure of the probability of a successful introduction of an agent.

Recuperability is measured in the time required to recover a specific system (infrastructure, facility, or plant) in terms of new productivity.

Vulnerability is a measure of simplicity by which a threatening agent can be introduced into a food product in sufficient quantities.

Effect is the percentage of productivity rate of an attacked food system on one facility/operation and is conversely related to the number of facilities that produce the same food product.

Recognizability is the degree to which an attacker can identify a target without replacement with other targets or system components.

Shock is a combined parameter of health, psychological and collateral national economic impacts of a successful attack on the targeted system (product, facility). The shock is considered to possess a national level of interest. The psychological impact of a successful attack on a food chain will be greater if there is a large number of deaths or the target of the attack has a historical, cultural, religious or other symbolic meaning to people (59).

\section{Action plan to reduce vulnerabilities}

Any deficiencies noted during the development of a general mitigation strategy should be examined so as to evaluate all possible threats and costs to resolving the problem. It is critical that each subject determines what is appropriate for them and determine the weaknesses in their mitigation strategies.

Once the vulnerability is identified as important, an action plan is developed and has to offer the solutions included in the Food Defence Plan together with information on the activities to be carried out, control of the progress of these activities and the timeline for completing the action plan. The FDA has developed a computer program (FDP Builder) that helps owners develop their own personalized Food Protection Plan (57). 
Table 2 Human poisonings and attempts of poisoning with known agents 1998-2018

\begin{tabular}{|c|c|c|c|}
\hline Country, date & Source-Agent & Motive & Incident \\
\hline Albania, 1998 & Water Supply - tritol & Political & $\begin{array}{l}\text { Five kilograms of tritol was thrown into the main waterline } \\
\text { and cut off the water supply to } 16 \text { villages in Albania (26). }\end{array}$ \\
\hline Israel, 1998 & Eggs - Salmonella & Political & $\begin{array}{l}\text { Counterfeit stamps on Salmonella-contaminated eggs caused } \\
\text { two deaths (28). }\end{array}$ \\
\hline Japan, 1998 & Food-arsenic & Unknown & $\begin{array}{l}\text { Four people died and } 64 \text { were admitted to the hospital for mass } \\
\text { food poisoning possibly involving arsenic contamination of } \\
\text { curry at a summer festival in Wakayama (27). }\end{array}$ \\
\hline Vietnam, 1998 & $\begin{array}{l}\text { Water and food - } \\
\text { cyanide }\end{array}$ & Financial gain & $\begin{array}{l}\text { At least } 13 \text { death and unknown number of ill persons was the } \\
\text { result of spiking water and food with cyanide. The couple } \\
\text { who poisoned family and people to steal from was arrested } \\
\text { and sentenced to death (28). }\end{array}$ \\
\hline $\begin{array}{l}\text { Australia, } \\
1999\end{array}$ & $\begin{array}{l}\text { Tea - oleander } \\
\text { extract }\end{array}$ & Personal & $\begin{array}{l}\text { A woman tried to poison her husband by putting oleander } \\
\text { extract in his tea over two months in small doses (27). }\end{array}$ \\
\hline China, 1999 & Soup - nitric acid & Business rivals & $\begin{array}{l}\text { Aiming to damage the business of a competing restaurant, } \\
\text { the owner hired four farmers to put nitric acid in a meat soup } \\
\text { served in the restaurant that resulted with poisoning of } 148 \\
\text { persons (28). }\end{array}$ \\
\hline China, 1999 & $\begin{array}{l}\text { Meat rolls - rat } \\
\text { poison }\end{array}$ & Business rivals & $\begin{array}{l}\text { After eating meat rolls that had been laced with rat poison at } \\
\text { a fast food restaurant in Deyang City, } 48 \text { people fell ill. Police } \\
\text { suspected the owner of the competing restaurant }(27) \text {. }\end{array}$ \\
\hline $\begin{array}{l}\text { New Zealand, } \\
1999\end{array}$ & $\begin{array}{l}\text { Water supply - } \\
\text { superphosphate } \\
\text { fertiliser }\end{array}$ & Unknown & $\begin{array}{l}\text { A worker at a water treatment plant found a broken padlock } \\
\text { and fertiliser poured into the water intake. The water supply } \\
\text { for the entire town was cut off and analyses were immediately } \\
\text { performed. Results showed a minimal concentration of the } \\
\text { fertiliser with no risk for human health (27). }\end{array}$ \\
\hline UK, 1999 & $\begin{array}{l}\text { Tea - copper } \\
\text { sulphate }\end{array}$ & Personal? & $\begin{array}{l}\text { A } 15 \text {-year old student tried to poison a teacher's coffee by } \\
\text { adding copper sulphate to it. The teacher noticed the taste and } \\
\text { was not poisoned ( } 27) \text {. }\end{array}$ \\
\hline USA, 1999 & $\begin{array}{l}\text { Water - potassium } \\
\text { cyanide }\end{array}$ & Unknown & $\begin{array}{l}\text { Seven students at a law school in Massachusetts were } \\
\text { admitted to emergency unit after drinking water from a cooler } \\
\text { contaminated with potassium cyanide (26). }\end{array}$ \\
\hline $\begin{array}{l}\text { Australia, } \\
2000\end{array}$ & Tablets - strychnine & Extortion & $\begin{array}{l}\text { A man from Brisbane laced headache tablets with strychnine } \\
\text { after sending extortion letters to the drug manufacturer. Four } \\
\text { people were poisoned (26). }\end{array}$ \\
\hline Canada, 2000 & Coffee - arsenic & Unknown & $\begin{array}{l}\text { Twenty-seven students got sick after drinking coffee from } \\
\text { a vending machine at the university. Police found traces of } \\
\text { arsenic in coffee machine (27). }\end{array}$ \\
\hline China, 2000 & $\begin{array}{l}\text { Food and water - rat } \\
\text { poison }\end{array}$ & Personal & $\begin{array}{l}\text { A man killed three neighbours and poisoned two with rat poison } \\
\text { spiked in food and water. He was sentenced to death }(27) \text {. }\end{array}$ \\
\hline India, 2000 & Food - pesticide & Unknown & $\begin{array}{l}\text { Six workers died in Punjab after two of their colleagues had } \\
\text { contaminated food with pesticide (26). }\end{array}$ \\
\hline India, 2000 & Liquor - cyanide & Unknown & $\begin{array}{l}\text { Two persons died after consuming liquor contaminated with } \\
\text { cyanide (26). }\end{array}$ \\
\hline Italy, 2000 & Wine - herbicide & Personal & $\begin{array}{l}\text { A parish priest in Sicily was hospitalised after drinking wine } \\
\text { that church sacristan spiked with herbicide (27). }\end{array}$ \\
\hline Japan, 2000 & $\begin{array}{l}\text { Curry sauce - } \\
\text { pesticide }\end{array}$ & Extortion & $\begin{array}{l}\text { The food company found that one of its curry sauce packets } \\
\text { pesticide in a Hamamatsu supermarket was contaminated } \\
\text { after receiving a threatening letter that the author would } \\
\text { poison the company's food products unless s/he was paid } 50 \\
\text { million yen (27). }\end{array}$ \\
\hline $\begin{array}{l}\text { Singapore, } \\
2000\end{array}$ & $\begin{array}{l}\text { Water tank - } \\
\text { kerosene and } \\
\text { turpentine }\end{array}$ & Unknown & $\begin{array}{l}\text { The water tank in a condominium block in Singapore had } \\
\text { been deliberately poisoned with kerosene and turpentine (26). }\end{array}$ \\
\hline
\end{tabular}




\begin{tabular}{llll}
\hline Country, date & Source - Agent & Motive & \multicolumn{1}{c}{ Incident } \\
\hline Turkey, 2000 & $\begin{array}{l}\text { Water supply }- \\
\text { insecticide }\end{array}$ & Unknown & $\begin{array}{l}\text { A news agency from Anatolia reported that a man was arrested } \\
\text { for attempting to poison the water supply of the village of } \\
\text { Kurusaray with insecticide (26). }\end{array}$ \\
\hline USA, 2000 & Coffee - rat poison & Unknown & $\begin{array}{l}\text { Seven employees of a company were hospitalized after } \\
\text { drinking coffee contaminated with rat poison (26). }\end{array}$ \\
\hline
\end{tabular}

\begin{tabular}{lll} 
USA, 2000 & $\begin{array}{l}\text { Food }- \text { domestic } \\
\text { cleaners }\end{array}$ & Personal \\
\hline USA, 2000 & Salsa - rat poison & Unknown \\
\hline China, 2001 & Noodles - rat poison & Business rival \\
\hline China, 2001 & $\begin{array}{l}\text { Soft drink }- \text { rat } \\
\text { poison }\end{array}$ & Personal \\
&
\end{tabular}

Three teenagers contaminated food with spit, urine, and household agents including oven cleaner and cleanser in a fast food restaurant in Rochester where they were employed (27).

In Jacksonville, 34 students were poisoned after two seventh graders allegedly contaminated the school cafeteria's salsa with rat poison (27).

At least 120 persons in 16 restaurants were poisoned after eating noodles that had been contaminated with rat poison in Hunan Province. The incident was a deliberate attempt to sabotage the noodle factory (27).

One person dies and 16 fell ill after drinking soft drinks spiked with rat poison. A man was practicing spiking poison at the supermarket before he poisoned his son and wife (27).

Ninety-two children at the primary school in Linxiang city fell sick after eating their school lunch contaminated with rat

China, 2002 $\begin{aligned} & \text { School meal - rat } \\ & \text { poison }\end{aligned}$ poison. Similar incident happened in the region of Xinjiang a year ago, when 100 primary students were admitted to hospital after eating a breakfast contaminated with rat poison that has been placed there by the teacher (27).

\begin{tabular}{|c|c|c|c|}
\hline China, 2002 & $\begin{array}{l}\text { Pastry dough - rat } \\
\text { poison (tetramine) }\end{array}$ & Business rival & $\begin{array}{l}\text { Up to } 400 \text { persons fell ill and } 41 \text { died by poisoning after } \\
\text { eating breakfast in a fast food shop. A business competitor } \\
\text { admitted to placing rat poison in the pastry dough ( } 27) \text {. }\end{array}$ \\
\hline China, 2002 & $\begin{array}{l}\text { Food - rat poison } \\
\text { (tetramine) }\end{array}$ & Personal & $\begin{array}{l}\text { A restaurant employee poisoned food with rat poison to get } \\
\text { revenge to boss who pay disputed. Five people died from } \\
\text { poisoning (28). }\end{array}$ \\
\hline China, 2002 & $\begin{array}{l}\text { Milk - rat poison } \\
\text { (tetramine) }\end{array}$ & Personal & $\begin{array}{l}\text { A man killed his wife and poisoned } 15 \text { others by putting rat } \\
\text { poison in milk (27). }\end{array}$ \\
\hline $\begin{array}{l}\text { Colombia, } \\
2002\end{array}$ & $\begin{array}{l}\text { Water supplies - } \\
\text { chromium, sodium, } \\
\text { nitrate, and pesticide } \\
\text { (parathion) }\end{array}$ & Political & $\begin{array}{l}\text { Authorities in Pitalito discovered that the local water supply } \\
\text { was poisoned with chromium, sodium, and nitrate that had been } \\
\text { delivered through one of the pipeline's inlets. A month after the } \\
\text { attack, authorities discovered a significant quantity of parathion } \\
\text { in the water supply of Libornia. No causalties resulted from } \\
\text { these incidents, which were attributed to the Revolutionary } \\
\text { Armed Forces of Colombia (FARC) (26). }\end{array}$ \\
\hline Russia, 2002 & $\begin{array}{l}\text { Vodka - potassium } \\
\text { cyanide }\end{array}$ & Political & $\begin{array}{l}\text { The Russian Federal Security Service discovered a container of } \\
\text { potassium cyanide solution near several bottles of vodka during a } \\
\text { search of the village of Alkhan-Kala, Chechnya. Analysis of the } \\
\text { bottles' contents determined that the potassium cyanide solution } \\
\text { had been mixed with the vodka Chechen rebels allegedly planned } \\
\text { to sell poisoned vodka at markets in Grozny (26). }\end{array}$ \\
\hline USA, 2002 & $\begin{array}{l}\text { Ground beaf - } \\
\text { nicotine }\end{array}$ & Personal & $\begin{array}{l}\text { A supermarket employee poisoned } 111 \text { people by contaminating } \\
\text { about } 250 \text { pounds of the store's ground beef with an insecticide } \\
\text { which has high concentrations of nicotine ( } 27) \text {. }\end{array}$ \\
\hline $\begin{array}{l}\text { Zimbabwe, } \\
2002\end{array}$ & Tea - pesticide & Religious & $\begin{array}{l}\text { Seven members of a religious sect died and another } 47 \text { fell } \\
\text { ill after drinking tea poisoned by pesticide near the town of } \\
\text { Nyazura. No arrests were made (28). }\end{array}$ \\
\hline China, 2003 & $\begin{array}{l}\text { Soya \& chilli sauce - } \\
\text { rat poison }\end{array}$ & Business & $\begin{array}{l}\text { A man poisoned more than } 60 \text { people by putting rat poison in } \\
\text { the soya } \& \text { chilli sauce at breakfast buffet due to the business } \\
\text { dispute ( } 27) \text {. }\end{array}$ \\
\hline
\end{tabular}




\begin{tabular}{|c|c|c|c|}
\hline Country, date & Source-Agent & Motive & Incident \\
\hline China, 2003 & $\begin{array}{l}\text { School breakfast } \\
\text { - rat poison } \\
\text { (tetramine) }\end{array}$ & Unknown & $\begin{array}{l}\text { After eating breakfast contaminated with rat poison } \\
\text { (tetramine), } 161 \text { students and staff at the Elementary School } \\
\text { in Hunan Province were admitted to the hospital (27). }\end{array}$ \\
\hline China, 2003 & $\begin{array}{l}\text { Water tank - } \\
\text { pesticide (phorate) }\end{array}$ & Business & $\begin{array}{l}\text { Approximately } 64 \text { residents were poisoned when a man } \\
\text { contaminated a water reservoir in Ruyang County with } \\
\text { pesticide (phorate). He admitted to poisoning the water hoping } \\
\text { that he will boost the selling of his water purifiers (26). }\end{array}$ \\
\hline China, 2003 & $\begin{array}{l}\text { Soup - rat poison } \\
\text { (tetramine) }\end{array}$ & Personal & $\begin{array}{l}\text { Five people died after eating mutton soup spiked with rat } \\
\text { poison. The man who poisoned the soup because of family } \\
\text { dispute targeted wife and her relatives (27). }\end{array}$ \\
\hline China, 2003 & Food - rat poison & Personal & $\begin{array}{l}\text { The widow of a farmer in central China, motivated by revenge, } \\
\text { poisoned } 33 \text { people by pouring rat poison into the food that } \\
\text { was being served at the funeral. Ten people died ( } 27) \text {. }\end{array}$ \\
\hline Italy, 2003 & $\begin{array}{l}\text { Bottled water - } \\
\text { bleach, acetone, } \\
\text { ammonia }\end{array}$ & Unknown & $\begin{array}{l}\text { About fifty people in more than } 20 \text { cities had to be treated } \\
\text { for a stomach pains after they drank bottled water spiked } \\
\text { with bleach, acetone or ammonia. No one has claimed } \\
\text { responsibility (27). }\end{array}$ \\
\hline $\begin{array}{l}\text { Netherlands, } \\
2003\end{array}$ & $\begin{array}{l}\text { Food products - } \\
\text { insecticide (folimat) }\end{array}$ & Extortion & $\begin{array}{l}\text { Four people were made ill as a result of the contamination of } \\
\text { various food product with insecticide (folimat), One man was } \\
\text { convicted for contamination aiming to extort money from } \\
\text { food manufacturers ( } 27) \text {. }\end{array}$ \\
\hline Russia, 2003 & $\begin{array}{l}\text { Caviar and coffee - } \\
\text { thallium }\end{array}$ & Personal & $\begin{array}{l}\text { A serial killer poisoned to death six people by putting } \\
\text { thallium in coffee and caviar. He was curious if he could kill } \\
\text { a man and leave no traces behind (28). }\end{array}$ \\
\hline USA, 2003 & Coffee - arsenic & Personal & $\begin{array}{l}\text { Sixteen people were poisoned and one man died from } \\
\text { drinking coffee spiked with arsenic at a Lutheran Church. } \\
\text { One of the church parishioners admitted to the crime in } \\
\text { a suicide note that he just wanted to give some people a } \\
\text { bellyache (33). }\end{array}$ \\
\hline $\begin{array}{l}\text { Indonesia, } \\
2004\end{array}$ & Juice - arsenic & Political & $\begin{array}{l}\text { A human right activist was killed on the flight to Amsterdam } \\
\text { when his juice was spiked with arsenic (27). }\end{array}$ \\
\hline Thailand, 2004 & Drink - insecticide & Unknown & $\begin{array}{l}\text { Thirty-seven children in kindergarten got ill when their } \\
\text { teacher mixed insecticide with chocolate drink (27). }\end{array}$ \\
\hline Ukraine, 2004 & $\begin{array}{l}\text { Food - } \\
\text { tetrachlorodibenzo- } \\
p \text {-dioxin (TCDD) }\end{array}$ & Political & $\begin{array}{l}\text { A Ukrainian opposition leader was poisoned with dioxin in } \\
\text { his food, probably soup ( } 27) \text {. }\end{array}$ \\
\hline USA, 2004 & Baby food - ricin & Unknown & $\begin{array}{l}\text { Three incidents occurred in California when the notes on } \\
\text { contamination of baby food with ricin were discovered in } \\
\text { the jars. The authorities found trace amounts of ricin and no } \\
\text { arrests have been made. Ricin was not in the purified form } \\
\text { that can be deadly (27). }\end{array}$ \\
\hline USA, 2004 & $\begin{array}{l}\text { Sports drink and } \\
\text { food - ethylene } \\
\text { glycol }\end{array}$ & Personal & $\begin{array}{l}\text { A man poisoned his wife with anti-freeze in sports drink and } \\
\text { food (27). }\end{array}$ \\
\hline $\begin{array}{l}\text { Australia, } \\
2005\end{array}$ & $\begin{array}{l}\text { Candy bars }- \text { rat } \\
\text { poison }\end{array}$ & Extortion & $\begin{array}{l}\text { Mars and Snickers bars were contaminated with rat poison in } \\
\text { an attempt to extort the money from the company. Nineteen } \\
\text { people felt ill after eating candy bars (28). }\end{array}$ \\
\hline India, 2005 & $\begin{array}{l}\text { Liquor - potassium } \\
\text { cyanide }\end{array}$ & Personal & $\begin{array}{l}\text { A woman killed her husband and his nephew by adding } \\
\text { potassium cyanide in liquor they drank. The wife told the } \\
\text { police that she was a victim of domestic violence }(27) \text {. }\end{array}$ \\
\hline Japan, 2005 & Food - thallium & Unknown & $\begin{array}{l}\text { A } 16 \text { year-old Japanese girl allegedly contaminated her } \\
\text { mother's food with doses of the rat poison containing } \\
\text { thallium causing her to slip into a coma. Her motives were } \\
\text { unclear ( } 27) \text {. }\end{array}$ \\
\hline
\end{tabular}




\begin{tabular}{|c|c|c|c|}
\hline Country, date & Source - Agent & Motive & Incident \\
\hline Taiwan, 2005 & Drink - cyanide & Extortion & $\begin{array}{l}\text { Energy drink poisoner was sentenced to death after killing } \\
\text { one person and injuring three others during an extortion } \\
\text { attempt (27). }\end{array}$ \\
\hline USA, 2005 & $\begin{array}{l}\text { Pudding and hot } \\
\text { chocolate - rat } \\
\text { poison }\end{array}$ & Personal & $\begin{array}{l}\text { A man poisoned his three children to death by putting rat } \\
\text { poison in their pudding and hot chocolate }(27) \text {. }\end{array}$ \\
\hline France, 2006 & Mousse - insecticide & Personal & $\begin{array}{l}\text { A middle-aged man killed his parents by spiking chocolate } \\
\text { mousse with insecticide after they refused to let him move in } \\
\text { with his girlfriend (27). }\end{array}$ \\
\hline $\begin{array}{l}\text { South Korea, } \\
2006\end{array}$ & $\begin{array}{l}\text { Coca-Cola - } \\
\text { herbicide }\end{array}$ & Extortion & $\begin{array}{l}\text { A woman has been arrested for allegedly lacing bottles of Coca- } \\
\text { Cola with herbicide in an attempt to extort the company (27). }\end{array}$ \\
\hline UK, 2006 & Tea - polonium-210 & Political & $\begin{array}{l}\text { An ex-KGB agent died after radioactive polonium- } 210 \text { was } \\
\text { allegedly put in his tea (27). }\end{array}$ \\
\hline USA, 2006 & $\begin{array}{l}\text { Grape juice - } \\
\text { dishwashing } \\
\text { detergent }\end{array}$ & Personal & $\begin{array}{l}\text { A man poured the dishwashing detergent into grape juice at } \\
\text { a drugstore where he worked to get back at his bosses. More } \\
\text { than } 40 \text { people got ill ( } 28) \text {. }\end{array}$ \\
\hline China, 2007 & $\begin{array}{l}\text { Noodles and milk - } \\
\text { rat poison }\end{array}$ & Unknown & $\begin{array}{l}\text { One man died and eleven employees fell sick after eating } \\
\text { noodles and soybean milk spiked with rat poison at the } \\
\text { government department canteen ( } 27) \text {. }\end{array}$ \\
\hline China, 2007 & $\begin{array}{l}\text { Porridge - rat poison } \\
\text { (fluoroacetamide) }\end{array}$ & Unknown & $\begin{array}{l}\text { One person died and } 203 \text { people were poisoned after eating } \\
\text { breakfast at a hospital restaurant. Investigators suspected the } \\
\text { water used for cooking porridge was contaminated with rat } \\
\text { poison fluoroacetamide. No further details were given by the } \\
\text { authorities (27). }\end{array}$ \\
\hline China, 2007 & $\begin{array}{l}\text { Water and food - } \\
\text { thallium }\end{array}$ & Personal & $\begin{array}{l}\text { A student put thallium into the water and food of his three } \\
\text { classmates who got sick (27). }\end{array}$ \\
\hline USA, 2007 & $\begin{array}{l}\text { Ground beef - rat } \\
\text { poison }\end{array}$ & Personal & $\begin{array}{l}\text { An employee was arrested and accused of putting rat poison } \\
\text { in packages of ground beef at the supermarket as a revenge to } \\
\text { her boss. The rat pellets were found before eaten ( } 27) \text {. }\end{array}$ \\
\hline China, 2008 & Rice - rat poison & Business rival & $\begin{array}{l}\text { Three people died and nine were hospitalised after eating } \\
\text { rice laced with a rat poison. Two men, who worked for rival } \\
\text { business, were arrested ( } 27) \text {. }\end{array}$ \\
\hline $\begin{array}{l}\text { Germany, } \\
2008\end{array}$ & $\begin{array}{l}\text { Gherkins - cleaning } \\
\text { fluid }\end{array}$ & Extortion & $\begin{array}{l}\text { A man poured cleaning fluid in the jar of gherkins in a } \\
\text { supermarket demanding a six-figure sum of money. The } \\
\text { contaminated jar was found before causing any harm (28). }\end{array}$ \\
\hline Iraq, 2008 & Cake - thallium & Political & $\begin{array}{l}\text { Two children died and nine were poisoned with thallium in } \\
\text { cake served in sports club. The source of the cake was bakery } \\
\text { that strongly supported previous regime (27). }\end{array}$ \\
\hline Japan, 2008 & $\begin{array}{l}\text { Dumplings } \\
\text { - pesticide } \\
\text { (methamidophos) }\end{array}$ & Personal & $\begin{array}{l}\text { Disgruntled employee injected pesticide in frozen dumplings } \\
\text { causing poisoning of } 10 \text { people }(28) \text {. }\end{array}$ \\
\hline Japan, 2008 & $\begin{array}{l}\text { Foodstuffs - sewing } \\
\text { needles }\end{array}$ & $\begin{array}{l}\text { Unknown } \\
\text { (business } \\
\text { rival?) }\end{array}$ & $\begin{array}{l}\text { Sewing needles were found in different foodstuffs } \\
\text { (watermelons, bananas, cabbage, etc.) in various } \\
\text { supermarkets. A woman was arrested for putting needles } \\
\text { in fish sold by business rival but it is not clear if she was } \\
\text { responsible for the other incidents (27). }\end{array}$ \\
\hline Sweden, 2008 & $\begin{array}{l}\text { Food? - Shigella } \\
\text { dysenteriae }\end{array}$ & Political & $\begin{array}{l}\text { One hundred and forty people was admitted to hospital after } \\
\text { eating in the office's cafeteria, All suffered from the illness } \\
\text { caused by the Shigella dysenteriae bacteria. Left-wing } \\
\text { extremists claimed the responsibility for the outbreak (28). }\end{array}$ \\
\hline UK, 2009 & $\begin{array}{l}\text { Curry - aconite ferox } \\
\text { (Indian herb) }\end{array}$ & Personal & $\begin{array}{l}\text { A woman laced a pot of curry with aconite ferox and } \\
\text { poisoned to death ex-boyfriend (28). }\end{array}$ \\
\hline USA, 2009 & $\begin{array}{l}\text { Salsa - pesticide } \\
\text { (methomyl) }\end{array}$ & Personal & $\begin{array}{l}\text { Disgruntled employees contaminated salsa in the restaurant } \\
\text { with pesticide causing more than } 40 \text { customers got sick (28). }\end{array}$ \\
\hline
\end{tabular}




\begin{tabular}{|c|c|c|c|}
\hline Country, date & Source - Agent & Motive & Incident \\
\hline China, 2010 & $\begin{array}{l}\text { Food - rat poisons } \\
\text { (broamadiolone and } \\
\text { chlrophacinone) }\end{array}$ & Extortion & $\begin{array}{l}\text { The extortionist spiked rice, fish, mushrooms, noodles with } \\
\text { rat poison in the supermarket. No reports on ingestion (28). }\end{array}$ \\
\hline China, 2011 & Milk - nitrite & Unknown & $\begin{array}{l}\text { Suspect has been accused of poisoning milk from two } \\
\text { dairies with nitrite which killed three children and } 36 \text { were } \\
\text { hospitalised (28). }\end{array}$ \\
\hline Israel, 2011 & $\begin{array}{l}\text { Food and drink - } \\
\text { pesticide }\end{array}$ & Political & $\begin{array}{l}\text { Three Arab construction workers are accused of attempting to } \\
\text { kill the six members of Jewish family by breaking into their } \\
\text { home and poisoning their grapefruit juice, house tap water, } \\
\text { and household food with pesticide (28). }\end{array}$ \\
\hline $\begin{array}{l}\text { Afghanistan, } \\
2012\end{array}$ & Food-bleach & Political & $\begin{array}{l}\text { The militant group claimed to have killed five people in } \\
\text { NATO military base by lacing their food with bleach. } \\
\text { According to the NATO-led International Security Assistance } \\
\text { Force (ISAF), bleach was discovered before it caused any } \\
\text { harm (28) }\end{array}$ \\
\hline China, 2013 & $\begin{array}{l}\text { Yoghurt - rat poison } \\
\text { (tetramine) }\end{array}$ & Business rival & $\begin{array}{l}\text { Two children died after eating yoghurt injected with } \\
\text { tetramine by rival kindergarten staff }(28) \text {. }\end{array}$ \\
\hline Japan, 2013 & $\begin{array}{l}\text { Snacks \& frozen } \\
\text { fast food - pesticide } \\
\text { (malathion) }\end{array}$ & Personal & $\begin{array}{l}\text { At least } 2,843 \text { got ill after eating Aqli Foods products that } \\
\text { were poisoned with malathion by a disgruntled factory } \\
\text { employee ( } 28) \text {. }\end{array}$ \\
\hline China, 2014 & $\begin{array}{l}\text { Snacks - rat poison } \\
\text { (tetramine) }\end{array}$ & Personal & $\begin{array}{l}\text { Four children died and over } 30 \text { were poisoned with rat poison } \\
\text { in pizza rolls left by a disgruntled employee in a room full of } \\
\text { napping children (28). }\end{array}$ \\
\hline China, 2014 & $\begin{array}{l}\text { Well water } \\
\text { - rat poison } \\
\text { (tetramethylene- } \\
\text { disulfotetramine) }\end{array}$ & Business rival & $\begin{array}{l}\text { A man who ran rival nursery made } 76 \text { children hospitalised } \\
\text { and two dead after poisoning water with rat poison }(28) .\end{array}$ \\
\hline Liberia, 2014 & $\begin{array}{l}\text { Well water - Ebola } \\
\text { virus }\end{array}$ & Political? & $\begin{array}{l}\text { At least } 16 \text { people are suspected to be dead because of well } \\
\text { poisoning in Liberia. Armed men injected the virus into the } \\
\text { water (29). }\end{array}$ \\
\hline UK, 2014 & Drinks - bleach & Personal & $\begin{array}{l}\text { Thirty-two workers and residents at care home for elderly } \\
\text { were poisoned with bleach that was put in water and juice } \\
\text { drinks by the malicious employee (28). }\end{array}$ \\
\hline China, 2015 & Tea - rat poison & Personal & $\begin{array}{l}\text { A man 'angry with the world' injected rat poison in tea } \\
\text { drinking products in the four supermarkets. The incident } \\
\text { resulted with one death and four hospitalisations (28). }\end{array}$ \\
\hline $\begin{array}{l}\text { Mozambique, } \\
2015\end{array}$ & $\begin{array}{l}\text { Beer - pesticide } \\
\text { (malathion?) }\end{array}$ & Unknown & $\begin{array}{l}\text { Nearly } 200 \text { people were hospitalized and } 72 \text { died after } \\
\text { drinking traditional beer at a funeral. The man who poisoned } \\
\text { beer with pesticide was arrested ( } 28) \text {. }\end{array}$ \\
\hline Pakistan, 2016 & $\begin{array}{l}\text { Sweets - pesticide } \\
\text { (chlorfenapyr) }\end{array}$ & Personal & $\begin{array}{l}\text { At least } 33 \text { people died after eating laddu sweets laced } \\
\text { with the insecticide chlorfenapyr. One of the shop owners } \\
\text { confessed to mixing the pesticide into the sweets after an } \\
\text { argument with his brother and co-owner (32). }\end{array}$ \\
\hline $\begin{array}{l}\text { Germany, } \\
2018\end{array}$ & $\begin{array}{l}\text { Baby food - ethylene } \\
\text { glycol (anti-freeze) }\end{array}$ & Extortion & $\begin{array}{l}\text { A man has been convicted of attempted murder after he } \\
\text { poisoned jars of baby food in the supermarkets with ethylene } \\
\text { glycol to extort money from retailers (31). }\end{array}$ \\
\hline $\begin{array}{l}\text { Australia, } \\
2018\end{array}$ & $\begin{array}{l}\text { Strawberries - } \\
\text { needles }\end{array}$ & Personal? & $\begin{array}{l}\text { Sewing needles were found in a number of strawberries sold } \\
\text { by a supermarket. Disgruntled ex-employee believed to be } \\
\text { behind the incident ( } 30) \text {. }\end{array}$ \\
\hline
\end{tabular}




\section{THREAT ASSESSMENT OF CRITICAL CONTROL POINTS (TACCP) IN THE FOOD/ WATER SUPPLY CHAIN}

TACCP is an integral part of crisis management of a company/facility/system or a national critical infrastructure. Company crisis management or company security management involves an expert for security and protection, fire protection, occupational safety, quality management system, food safety system, information security system. Most of the food industry is familiar with crisis management or risk management systems (ISO 31000: 2009) (60), and they already estimate risks through quality management and food safety systems (53).

Threats should be studied realistically, with scenarios in which it is possible to see what would happen or where the possible omissions are. Dangers stem from agents that can cause harm (biological, chemical, radiological, physical) or a person who is capable of inserting this agent into food/drinking water at specific critical positions of the food production system, facility or food transport. Supervision of persons entering a facility and coming close to food/water at any stage of processing or the employees of the company (contract staff, carriers) as well as agent supervision at the place of storage help to reduce the risk and threat of food contamination. The supply of ingredients and foodstuffs to be incorporated into the food product must be from reliable sources and they must have certain quality and safety certificates or come from facilities that have a developed food protection plan. Each transport to and from the facility must be arranged and controlled in such a way as to know which person transports the food or ingredients (announcement, security check). A particular risk is the globalization of the food supply chain, as the ingredients are often purchased all over the world and then incorporated into a single product (48).

In 2014, Croatia passed a crisis management plan regarding the food and feed safety which provides answers to potential crisis situations and "emergency situations", ways of managing risks in such situations, and ways of coordinating national and local services (61).

\section{Prevention of attacks - mitigation strategies at critical points in the food supply chain}

A mitigation strategy is a practice implemented to significantly reduce or eliminate weak points that were previously identified in the assessment of vulnerability and risk. It can be implemented throughout the entire process of food production, from agriculture, through processing to distribution and retail.

Preventive actions and mitigation strategies in food/ water facilities comprise installing fences, control of entry to system areas that are critical points or have been deemed vulnerable in the vulnerability assessment, video surveillance on critical points, marking (badges) authorized employees in processing facilities, security check for the employees, and controlling visitor (badges) entrance, controlling vehicles for transportation that enter the facility.

Agents that pose a threat for the food/water supply chain branch into four categories: physical agents such as glass, needles, metals, objects; biological agents are bacteria (e.g. Shiga toxin-producing (STEC) Escherichia coli O157:H7), viruses (e.g. adenoviruses and rotavirus), chemical agents (toxic metals such as lead, industrial chemicals such as ethylene glycol, toxins such as botulinum), and radioactive substances (e.g. polonium).

Mitigation strategies are the first and fundamental component of any food defence plan.

\section{Food defence plan}

Food defence is defined as the protection of the national food supply chain from deliberate and targeted acts of intentional contamination and unauthorized penetration into the food chain (34).

There are three basic elements that have to be considered when protecting food, namely 1) prevention, 2) response to an event, and 3) system recovery. In terms of preventive activities, the management structure of the company or country should develop a strategy for the potential intentional food contamination accident like facility monitoring, withdrawal procedures for food product, investigation of suspicious activities and assessment of related programs.

Designing of a food/water defence plan is important for food management at national levels as well as the food industry level. It is necessary to be aware of all the potential weaknesses of the food/ water supply chain system, to know potential indicators or signs of deliberate contamination, but also any possible errors in the assessment. It is necessary to evaluate possible types of losses that can cause intentional contamination or long-term effects on the global supply chain. This is possible if a food defence plan for the prevention of intentional contamination of the supply chain is designed (62).

\section{NATIONAL RISK MANAGEMENT}

\section{National response to food terrorist attacks}

Nobody can prepare for a food/water terrorist attack, but a country should have tools and activities prepared that could be applied in the right moment. If the mitigation strategy was not helpful, and an attack to food/water critical infrastructure did occur, the country has to react.

National preparedness for food terrorism emergencies should comprise food defence systems implemented into the food supply chain through vulnerability assessment, mitigation strategies, action plans and food defence plans.

Ministries for health and agriculture in cooperation with departments for homeland security as well as public health 


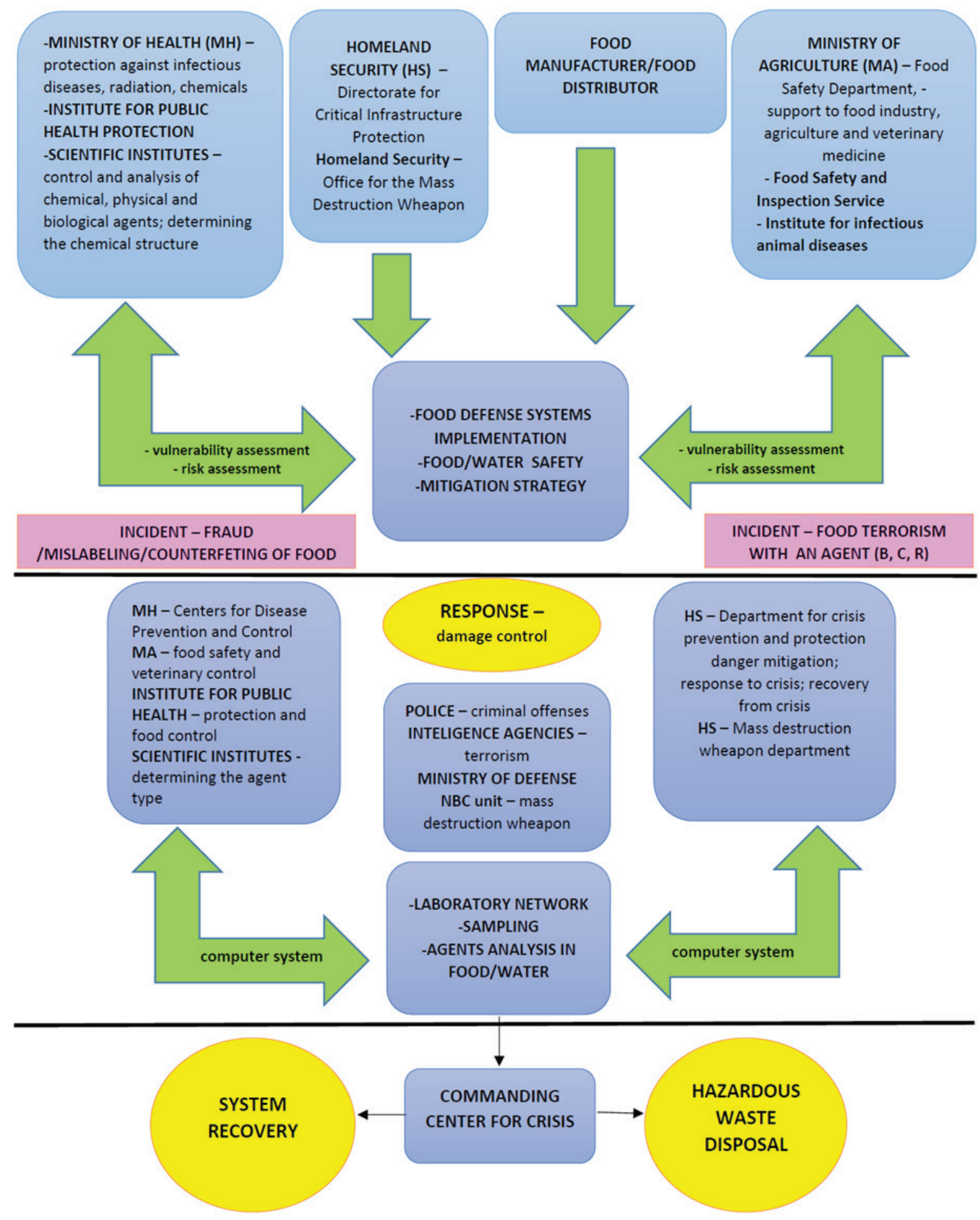

Figure 5 National response to a food terrorist attack

and scientific institutions should provide a framework for the implementation of food defence systems (Figure 5).

The national strategy for food protection should be in harmony with the national system for emergency management, national response framework, national plan for the infrastructure protection, and national preparedness goals (56). The strategy prescribes the procedures for the ministries of agriculture and health regarding preparedness (agriculture and food sector), detection of incident, emergency response, system recovery. The ministries of agriculture and health are the leading departments in terms of food terrorism emergency and all state agencies, or departments, or scientific institutes should provide support to them. The police department should have knowledge regarding food emergencies and food safety. Local hospitals should adjust and train for such crises. 
A national food emergency response (food emergency response team) should be designed in terms of who will react first (security agencies, institutes, ministries), who will quickly determine the type of CBRN agent used, (institutes and laboratories), how to control damage, how to cure victims, how to recover the system, and how to dispose of hazardous waste (Figure 5 and 6).

A food emergency response plan (FERP) is part of the national emergency response plan, and all agencies involved should have annual training for their staff. The team is made of state health and agriculture staff, as emergencies could involve larger numbers of casualties (63).

During the incident detection and response phase, it is assessed whether the incident was intentional or unintentional. Figure 6 shows the steps taken during this first phase. Once intentional food contamination is discovered or suspected, the appropriate government institutions (local police, state health authorities, state agriculture authorities) should be notified.

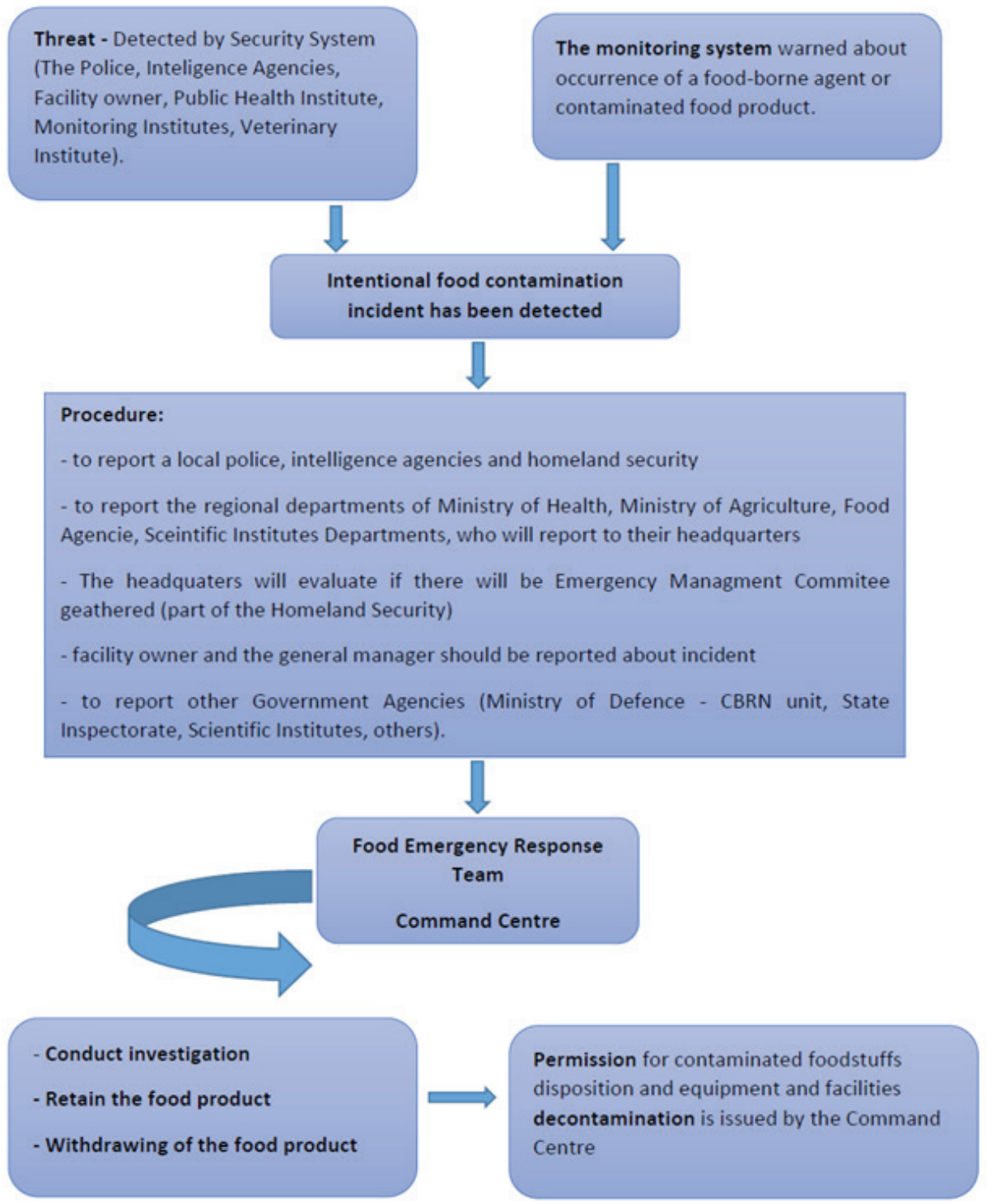

Figure 6 Food Emergency Response
After intentional food/water contaminations, the command centre and food emergency response team should conduct an investigation with police and security agencies. Food products should be detained and withdrawn, with urgent agent detection (Figure 6).

The national emergency response team should be organised and equipped (laboratory equipment for rapid agent detection, highly trained personal) so it could investigate outbreaks in animals, plants and humans (56) as well as tracking of biological threats.

The identification of an agent should be conducted in cooperation with scientific and public health institutes and the spreading of the disease prevented (Figure 5, 6).

During a crisis, it is recommended to also consider the contaminated food waste disposal with regard to the agent type and their characteristics. contaminated food product. 


\section{Food emergency recovery}

System recovery means ensuring agricultural and food production after the food emergency crisis returns into the pre-emergency conditions. Collaboration with the private sector on the development of production recovery plans should be established to move forward rapidly with agriculture, food production and international trade. The national and private sector should perform exercises on food defence plans with a view to long-term recovery. Prompt removal and efficient disposal of contaminated agricultural or food products, infected plants and animals is recommended as well as decontamination and restoration of the food sector affected by the crisis (56).

\section{Hazardous waste management}

Disposal and decontamination of such contaminated products cannot be carried out until the investigation is complete and its disposal ordered. The development of a disposal and decontamination plan can be initiated during the incident discovery and incident response phases.

The disposal of CBRN contaminated food product or water are carried out by special teams or units in coordination with the command centre based on the expert advice of competent agencies (e.g. environmental protection agency, food safety agency) (40).

Firstly, if corrective measures can be provided (decontamination of the food product or food facility), that would be the first step. If this is not feasible, the second step is waste disposal.

Waste should be put in disposal categories (I-IV), which suggests the manner of disposal. Food contaminated with CBRN agents is in the IV waste (hazardous waste) category. There are two different techniques: landfill disposal or combustion techniques (40).

Landfill disposals have to be coated with an almost impermeable layer to prevent waste from migrating to the environment, and with a designed cover for surface infiltration protection. This kind of landfill should have a double liner; leachate collection and removal system; a leak detection system, and control water flow and runoff to prevent the migration of hazardous ingredients during at least 25 years of weather (64). For contaminated liquid foodstuffs or any secondary wastewater from the decontamination process, surface indoor pools or landfill may be appropriate.

Combustion is also commonly used when managing hazardous waste. Combustion can permanently destroy certain toxic organic compounds contained in hazardous waste by breaking their chemical bonds and converting them into their constituent elements. This technique can also reduce the amount of waste that needs to be disposed of on land by converting solids and liquids to ash.

During combustion, organic waste is converted from solids and liquids into gases. These gases pass through flames, heat further, and eventually become so hot that their organic compounds break down into constituent atoms. These atoms combine with oxygen to form stable gases that are released into the atmosphere after passing through air pollution control devices (65).

Some hazardous waste can be characterized as medical waste (biological contaminant) and should be disposed as such. Medical waste incineration is most commonly used to dispose of this waste. The incineration of this waste decreases its volume and destroys the pathogens in the waste material (66).

For incidents involving the contamination of foodstuffs with radioactive materials, the waste products would be considered low level radioactive waste or transuranic waste, depending on the radioisotope and the amount of radioactive material used. If the pollution consists of a hazardous chemical and a radioactive component, then the resulting waste is called mixed waste (e.g. low-level mixed radioactive waste). Low-level radioactive waste is usually removed by shallow burial in engineered landfills, as required by the Nuclear Energy Commission. Low-level radioactive waste is buried in licensed facilities several meters into the ground in shallow trenches near the surface, usually in the tanks in which they were delivered. This kind of waste can also be stored (transport containers) in landfills that are not easily accessible to allow the destruction of short-lived radioactive materials. Such landfills should be safeguarded (67).

\section{CONCLUSIONS}

The basic idea of homeland security is to protect and defend the national critical infrastructures as well as the food and water supply chain regarding the main food industry in all phases (land cultivation, livestock, processing and food production, transportation, storehouses and retail). A country should pass a national strategy on the defence of food and water supply chain, as well as instructions for the state agencies included in the response to possible acts of food terrorism or intentional contamination of food. The strategy should be recommended or obligatory for counties or bigger cities especially with major food/water industries or cities with main system critical points. All possible threats (chemicals, industry/departments that use chemicals, poisons, pesticides, industry/departments with microbiological material, industry/departments that use radioactive elements) should be secured and be put under the surveillance of local or national agencies.

A good way of thinking is to secure at least one main food/water supply chain that would be reliable when an asymmetric attack on infrastructure occurs, because a country should be able to continue to live and function despite a terrorist attack. National food/water systems are well secured only in situations where they have implemented functional food defence systems that are periodically evaluated and self-monitored. Food defence systems can 
be implemented in all food/water supply systems larger and smaller.

Food defence systems should firstly define the critical points and evaluate the vulnerability of a food system's or supply chain's critical points. Secondly, mitigation strategies should be written in an action plan for all critical points. This action plan should be self-evaluated and monitored with verification by responsible persons. If action plans already exist, oversights should ensure that they be newly rewritten and improved.

State agencies have to do everything in their power to prevent terrorist attacks on the food/water supply chain, but the state must be prepared for the moment when a terrorist attack occurs. Strategies for food terrorism should be written and well known throughout a national crisis management system. National crisis management and damage control are very important in the moment of food terrorist attack, because there are procedures about the response to crisis (scientific institutes and agencies, public health institutes, food and environmental agencies, police departments, intelligence agencies, ministries of defence, departments of homeland security). Responses to crises should answer questions about the agent used in food/water terrorist attack and about the perpetrators or offenders.

\section{REFERENCES}

1. Johns Hopkins Center for Public Health Preparedness. Bioterrorism and Food Safety [displayed 13 November 2019]. Available at https://www.jhsph.edu/research/centersand-institutes/johns-hopkins-center-for-public-healthpreparedness/tips/topics/food security.html

2. World Health Organization (WHO). Terrorist Threats to Food: Guidance for Establishing and Strengthening Prevention and Response Systems, revision 2008 [displayed 1 July 2019]. Available at https://apps.who.int/iris/bitstream/ handle/10665/42619/9241545844.pdf?sequence=1\&isAllowed=y

3. Mohtadi H, Murshid AP. Risk analysis of chemical, biological, or radionuclear threats: Implications for food security. Risk Anal 2009;29:1317-35. doi: 10.1111/j.1539-6924.2009.01260.x

4. CBRNE-Terrorism Newsletter - October 2013 (Special Collection) [displayed 1 July 2019]. Available at https://www. cbrne-terrorism-newsletter.com/resources/2013_5 Special_ Issue Agroterrorism.pdf

5. Meulenbelt S. Assessing chemical, biological, radiological and nuclear threats to the food supply chain. Glob Secur Heal Sci Policy 2018;3:14-27. doi: 10.1080/23779497.2018.1509675

6. Brinkman H, Hendrix CS. Food Insecurity and Violent Conflict: Causes, Consequences, and Addressing the Challenges. Occasional paper no. 24. World Food Programme 2011. doi: 10.13140/2.1.3379.2003

7. Chemical Weapons Convention (CWC). Convention on the Prohibition of the Development, Production, Collection and Use of Chemical Weapons and on its Destruction. Geneva: CWC; 1993.

8. Bacteriological (Biological) and Toxin Weapons Convention (BTWC). The Convention on the Prohibition of the Development, Production and Stockpiling of Bacteriological
(Biological) and Toxin Weapons and on their Destruction. London, Moscow, and Washington (DC): BTWC; 1972.

9. Regulation EC No 2002/178/EC. The general principles and requirements of food law, establishing the European Food Safety Authority and laying down procedures in matters of food safety [displayed 25 June 2019]. Available at https:/eur-lex. europa.eu/legal-content/EN/ALL/?uri=CELEX:32002R0178

10. Directive EC 2008/114/EC on the identification and designation of European critical infrastructures and the assessment of the need to improve their protection [displayed 25 June 2019]. Available at https://eur-lex.europa.eu/legal-content/ EN/TXT/PDF/?uri=CELEX:32008L0114\&from=EN

11. Zakon o kritičnim infrastrukturama [Critical Infrastructures Act, in Croatian]. Narodne novine 56/2013.

12. Government of the Republic of Croatia. Nacrt konačnog prijedloga zakona o Domovinskoj sigurnosti, 2017 [The final draft on Homeland Security Act, 2017, in Croatian].

13. Parliament of the United Kingdom. Security Service Act, 1989.

14. Parliament of the United Kingdom. Terrorism Act, 2000.

15. Parliament of the United Kingdom. Anti-Terrorism, Crime and Security Act, 2001.

16. United Kingdom Centre for the Protection of National Infrastructure (UK CPNI). Defending Food and Drink Pass 96:2010 [displayed 25 June 2019]. Available at http://www. continuityforum.org/sites/default/files/images/PAS96_vis14.pdf

17. United Kingdom Centre for the Protection of National Infrastructure (UK CPNI). Critical National Infrastructure [displayed 25 June 2019]. Available at https://www.cpni.gov. uk/critical-national-infrastructure-0

18. Department of Homeland Security (DHS). Homeland Security Act of 2002 (Critical Infrastructure Information Act of 2002) November 25, 2002.

19. Homeland Security Presidential Directive 9, Defense of United States Food and Agriculture (January 30, 2004) [displayed 25 June 2019]. Available at https://www.govinfo. gov/content/pkg/PPP-2004-book1/pdf/PPP-2004-book1doc-pg173.pdf

20. U.S. Government Printing Office. Public Health Security and Bioterrorism Preparedness and Response Act Public Law 107-188. June 12, 2002.

21. National Center for Emerging and Zoonotic Infectious Diseases (NCEZID). Bioterrorism Agents/Diseases, 2018 [displayed 16 November 2019]. Available at https:// emergency.cdc.gov/agent/agentlist-category.asp

22. U.S. Food and Drug Administration. Food Safety Modernization Act (FSMA), 2010 [displayed 25 June 2019]. Available at https://www.fda.gov/food/foodsafetymodernization-act-fsma/full-text-food-safetymodernizationact-fsma

23. European e-justice. Law [displayed 15 November 2019]. Available at https://e-justice.europa.eu/content_law-2-en.do

24. USA - Criminal Law 18 U.S. Code Title 18 - Crimes and Criminal Procedure, Part I - Crimes, 1948.

25. Kazneni zakon [Criminal Code, in Croatian]. Narodne novine $125 / 2011$.

26. Mohtadi H, Murshid A. A Global Chronology of Incidents of Chemical, Biological, Radioactive and Nuclear Attacks: 1950-2005. U.S. Department of Homeland Security 2006.

27. Dalziel GR. Food defence incidents 1950-2008: A chronology and analysis of incidents involving the malicious 
contamination of the food supply chain. Singapore: Centre of Excellence for National Security (CENS); 2009.

28. Brainard J, Hunter PR. Contextual factors among indiscriminate or large attacks on food or water supplies, 1946-2015. Heal Secur 2016;14:19-28. doi: 10.1089/ hs. 2015.0056

29. Sridharan V. Ebola outbreak: armed Liberians "poison" wells killing villagers under pretext of Ebola. International Business Times, August 6, 2014 UK [displayed 16 November 2019]. Available at https://www.ibtimes.co.uk/ebolaoutbreak-armed-liberian-men-poison-wells-kill-residentsunder-pretext-epidemic-1459917

30. Horn A, Vujkovic M. Strawberry recall: Disgruntled exemployee believed to be behind sewing needles in strawberries. ABC News, 13 September 2018, Australia [displayed 16 November 2019]. Available at https://www. abc.net.au/news/2018-09-12/strawberry-investigation-aftersewing-needles-found-inside/10237954

31. Khan S. German man poisoned baby food and put it back on supermarket shelves in bid to extort money. The Independent, 23 October 2018, UK [displayed 16 November 2019]. Available at https://www.independent.co.uk/news/world/ europe/man-poisoned-baby-food-supermarkets-germanyextort-money-a8597811.html

32. Sims A. Pakistani sweet shop owner admits killing 30 people with poison-laced sweets. The Independent, 6 May 2016, UK [displayed 16 November 2019]. Available at https://www. independent.co.uk/news/world/asia/pakistani-sweetshopowner-admits-killing-30-people-with-poison-lacedsweets-a7017236.html

33. Mills DA, Tomassoni AJ, Tallon LA, Kade KA, Savoia ES Mass arsenic poisoning and the public health response in Maine. Disaster Med Public Health Prep 2013;7:319-26. doi: 10.1001/dmp.2011.1

34. U.S. Food and Drug Administration. Food Defense Guidance Documents \& Regulatory Information [displayed 25 June 2019]. Available at https://www.fda.gov/food/guidancedocuments-regulatory-information-topic-food-and-dietarysupplements/food-defense-guidance-documents-regulatoryinformation

35. SQF code 8.1, Edition, 2019 [displayed 25 October 2019] Available at https://www.sqfi.com/resource-center/draft-sqfcode-downloads-edition-8-1/

36. Food Defence Guides for Warehouses and Distribution Centres [displayed 25 October 2019]. Available at https:// www.fsis.usda.gov/shared/PDF/Guidance_Document Warehouses.pdf

37. Food Defence Guidelines for the Transportation and Distribution of Meat, Poultry, and Processed Egg Products [displayed 25 October 2019]. Available at https://www.fsis. usda.gov/wps/wcm/connect/4f9d737a-1f3e-49ff-851b74884fa946bd/Transportation_Security_Guidelines. pdf?MOD=AJPERES

38. Food Defence Guide to Freshwater Fish [displayed 25 October 2019]. Available at https://www.fsis.usda.gov/wps/ $\mathrm{wcm} /$ connect/fc8c5e29-acf2-4636-8963-5f0011075f08/ Food-Defense-Guidelines-Catfish.pdf?MOD=AJPERES

39. Guide for Security Practices in Transporting Agricultural and Food Commodities [displayed 25 October 2019]. Available at https://www.fsis.usda.gov/wps/wcm/connect/8e $71743 \mathrm{c}-$ 5d6e-46b1-99aa-df9d245ac2da/aftcsecurguidfinal19. pdf?MOD=AJPERES
40. Guidelines for the Disposal of Intentionally Adulterated Food Products and the Decontamination of Food Processing Facilities [displayed 25 October 2019]. Available at https:// www.fsis.usda.gov/shared/PDF/Disposal_Decontamination Guidelines.pdf

41. Deily K. Dispelling Food Waste Myths to Protect Our Food Supply. 3BL Media, 16 October 2017, USA [displayed 17 November 2019]. Available at https://www.3blmedia.com/ News/Dispelling-Food-Waste-Myths-Protect-Our-FoodSupply

42. Food Safety System Certification, FSSC 22000 Version 4.1: July 2017, Foundation FSSC 22000, The Netherland [displayed 25 October 2019]. Available at https://www. fssc22000.com/

43. The British Retail Consortium, 2018, BRC Global standard food safety [displayed 25 October 2019]. Available at https:// www.brcglobalstandards.com

44. British Standard Institution. PAS 96:2017, Guide to protecting and defending food and drink from deliberate attack [displayed 25 October 2019]. Available at https://www. food.gov.uk/sites/default/files/media/document/ pas962017_0.pdf

45. International Featured Standard. IFS Food Version 6.1., 2017 [displayed 25 October 2019]. Available at https://www. procert.ch/admin/data/files/publication file/file en/34/ifs food_v6_1_en.pdf?!m=1512663544

46. An Introduction to Food Security Awareness FD251A 7-132010 [displayed 13 November 2019]. Available at https:// www.fda.gov/media/78973/download

47. Ellison HD. Handbook of Chemical and Biological Warfare Agents. Boca Raton: CRC Press; 2000.

48. Alvarez MJ, Alvarez A, De Giacomo M, De Maggio MC, Onori R, Oses A, Sarriegi JM, Setola R, Trombetta M. A risk assessment of the food supply chain: vulnerability against terrorist or criminal contamination. Int J Food Safety, Nutr Public Heal 2011;4:63-82. doi: 10.1504/ijfsnph.2011.042575

49. USA National Center for Food Protection and Defense (NCFPD).

50. Olson D. Agroterrorism; threats to America's economy and food supply. FBI Law Enforcement Bulletin [displayed 12 October 2019]. Available at https://leb.fbi.gov/articles/ featured-articles/agroterrorism-threats-to-americaseconomy-and-food-supply

51. EC Regulation No 852/2004. The hygiene of the foodstuffs [displayed 25 June 2019]. Available at https://eur-lex.europa. eu/legal-content/GA/TXT/?uri=CELEX:32004R0852

52. Zakon o veterinarstvu [Veterinary Act, in Croatian]. Narodne novine 82/2013.

53. Puhač Bogadi N, Banović M, Babić I. Food defence system in food industry: perspective of the EU countries. J Verbr Lebensm 2016;11:217-26. doi: 10.1007/s00003-016-1022-8

54. Global Food Safety Initiative (GFSI) [displayed 15 November 2019]. Available at https://mygfsi.com/

55. DeNileon GP. The who, what, why, and how of counterterrorism issues. Am Water Work Assoc 2001:78-85. doi: 10.1002/j.1551-8833.2001.tb09208.x

56. 21 USC Ch. 27: Food Safety Modernization. Subchapter I - Improving capacity to prevent food safety problems [displayed 25 October 2019]. Available at https://uscode. house.gov/view.xhtm1?path=/prelim@title21/ chapter27\&edition=prelim 
57. United States Department of Agriculture, Food Safety and Inspection Service. Functional Food Defense Plans [displayed 25 June 2019]. Available at https://www.fsis.usda. gov/wps/portal/fsis/topics/food-defense-defense-andemergency-response/functional-food-defense-plan/ functional-plans

58. Yadav V, Sharma A. A free software for food industries to ensure food safety: CARVER + Shock. Compr Rev Food Sci Food Saf 2011;10:109-17. doi: 10.1111/j.1541-4337. 2010.00142.x.

59. U.S. Food and Drug Administration. Carver+Shock software [displayed 25 June 2019]. Available at https://www.fda.gov/ food/food-defense-programs/carver-shock-primer

60. Puhač Bogadi N. Upravljanje rizikom od glutena u prehrambenoj industriji [Risk management of gluten in the food industry; in Croatian]. [PhD thesis]. Zagreb: Faculty of Food Technology and Biotechnology, University of Zagreb; 2019.

61. Ministry of Agriculture and Ministry of Health. Plan upravljanja krizom u području sigurnosti hrane i hrane za životinje, 2014. [Plan for crisis management in the field of the safety of food and feed, 2014, in Croatian] [displayed 12 October 2019]. Available at http://www.veterinarstvo.hr/ UserDocsImages/HranaZaZiv/Plan upravljanja krizom u području sigurnosti hrane i hrane za životinje.pdf

62. U.S. Food and Drug Administration. Food Defense Plan Builder [displayed 25 June 2019].Available at https://www. fda.gov/food/food-defense-tools-educational-materials/fooddefense-plan-builder

63. National Association of State Departments of Agriculture (NASDA), 2011. Food Emergency Response Plan Template, version 4.0 [displayed 25 October 2019]. Available at https:// www.k-state.edu/nabc/docs/ferp/FERPV4.pdf
64. U.S. Environmental Protection Agency (U.S. EPA). Safer Disposal For Solid Waste, The Federal Regulations for Landfills, March 1993 [displayed 25 October 2019]. Available at https://archive.epa.gov/epawaste/nonhaz/ municipal/web/pdf/safedis.pdf

65. U.S. Environmental Protection Agency (U.S. EPA). Municipal Waste Combustors - Background Information for Proposed Standards: 111(b) - Model Plant Description and Cost Report. OAR-2004-0273-0003

66. U.S. Environmental Protection Agency (U.S. EPA). Standards of Performance for New Stationary Sources and Emission Guidelines for Existing Sources: Hospital/ Medical/ Infectious Waste Incinerators. 40 CFR Part 60. Vol 62, No 178, 1997 [displayed 25 October . Available at https://www. govinfo.gov/content/pkg/FR-1997-09-15/pdf/97-23835.pdf

67. U.S. Nuclear Regulatory Commission (U.S. NRC). Radioactive Waste: Production, Storage, Disposal, 2002 [displayed 25 October 2019]. Available at https://www.nrc. gov/docs/ML1512/ML15127A029.pdf

68. U.S. National Library of Medicine. TOXNET [displayed 17 November 2019]. Available at https://toxnet.nlm.nih.gov/

69. Centers for Disease Contol and Prevention (CDCP). Information on Specific Types of Emergencies, 2018 [displayed 17 November 2019]. Available at https:// emergency.cdc.gov/hazards-specific.asp

70. Burrows WD, Renner SE. Biological warfare agents as threats to potable water. Environ Health Perspect 1999;107:975-84. doi: 10.1289/ehp.99107975

71. Spink J, Moyer DC. Defining the public health threat of food fraud. J Food Sci 2011;76:1-7. doi: 10.1111/j.1750-3841. 2011.02417.x

\section{Sustavi zaštite hrane kao odgovor na potencijalni teroristički čin putem hrane}

Potencijalni teroristički napad na kritične infrastrukture može prouzročiti problem za stabilnost i funkcioniranje države. Opskrbni lanci hranom i vodom važne su državne infrastrukture, stoga država ima obvezu osigurati dovoljne količine hrane i vode svom pučanstvu. Namjerno trovanje hrane kazneno je djelo koje nastaje terorističkim činom (politički i ideološki motivi) ili izazivanjem straha (terora) među ljudima. Sustavi zaštite hrane mogu pomoći pri procjeni ranjivosti, određivanju strategija ublažavanja terorističkoga napada te pri procjeni rizika i sprječavanju rizika od terorističkoga napada. U procjenu i sprječavanje rizika pripada i kontrola prometa i proizvodnje potencijalnih kemijskih, bioloških, radioloških i nuklearnih (KBRN) agensâ ili srodnih materijala u državi i izvan nje. Kada se teroristički napad dogodi, bitan je brz i organiziran odgovor države u smislu određivanja vrste korištenog agensa, zbrinjavanja oboljelih, nastavka funkcioniranja opskrbe hranom i vodom nakon napada te oporavka napadnutoga sustava. Planiranje zaštite hrane kao dio strategije za borbu protiv terorizma hranom odnosno agroterorizma treba uključiti razmatranje globalnoga lanca opskrbe sastojcima hrane koja se nabavlja diljem svijeta (proizvođački certifikati). Prevencija terorističkoga napada na hranu bolji je izbor nego upravljanje kriznim događajem (počinjeni napad), ali država bi trebala imati spreman odgovor na sve opcije.

KLJUČNE RIJEČI: KBRN agens; kritična infrastruktura; namjerno zagađenje hrane; procjena rizika; ranjivost sustava 